
\section{9} 20 1

\title{
Review of snow cover variation over the Tibetan Plateau and its influence on the broad climate system
}

Qinglong You ${ }^{1 *}$, Tao $\mathrm{Wu}^{2}$, Liuchen $\mathrm{Shen}^{2}$, Nick Pepin ${ }^{3}$, Ling Zhang ${ }^{5}$, Zhihong

Jiang $^{4}$, Zhiwei Wu ${ }^{1}$, Shichang Kang ${ }^{5,6}$, Amir AghaKouchak ${ }^{7}$

1. Department of Atmospheric and Oceanic Sciences \& Institute of Atmospheric

Sciences, Fudan University, 200438, Shanghai, China;

2. College of Geography and Environment Sciences, Zhejiang Normal University, Jinhua 321004, China;

3. Department of Geography, University of Portsmouth, PO1 3HE, U.K. ;

4. Key Laboratory of Meteorological Disaster, Ministry of Education (KLME), Nanjing University of Information Science and Technology (NUIST), Nanjing, 210044, China;

5. State Key Laboratory of Cryospheric Science, Chinese Academy of Sciences, Lanzhou 730000, China;

6. CAS Center for Excellence in Tibetan Plateau Earth Sciences, Beijing 100101, China;

7. Department of Civil and Environmental Engineering, University of California, Irvine, CA 92697, U.S;

22 * Corresponding author E-mail address: yqingl@126.com 


\section{Abstract:}

Variation in snow cover over the Tibetan Plateau (TP) is a key component of climate change and variability, and critical for many hydrological and biological processes. This review first summarizes recent observed changes of snow cover over the TP, including the relationship between the TP snow cover and that over Eurasia as a whole; recent climatology and spatial patterns; inter-annual variability and trends; as well as projected changes in snow cover. Second, we discuss the physical causes and factors contributing to variations in snow cover over the TP, including precipitation, temperature, and synoptic forcing such as the Arctic Oscillation and the westerly jet, and large scale ocean-atmosphere oscillations such as the El Niño-Southern Oscillation (ESNO), the Indian Ocean dipole, and the southern annular mode. Third, linkage between snow cover over the TP and subsequent weather and climate systems are discussed, including the East and South Asian Summer Monsoons, and their subsequent precipitation regimes. Finally, new perspectives and unresolved issues are outlined, including changes in extreme events and related disasters (e.g., avalanches), the use of novel datasets, the possible elevation dependency in snow cover change, expected snow cover changes under $1.5^{\circ} \mathrm{C}$ and $2^{\circ} \mathrm{C}$ global warming, the physical mechanisms modulating climate extremes in the region, and the linkage between snow cover variation and atmospheric pollution. Despite a large body of work over the TP, we argue that there is a need for more comparative studies using multiple snow datasets, and snow cover information over the western TP and during summer would benefit from more attention in the future. 
Key words: Tibetan Plateau; Snow cover; Asian summer monsoon; Climate change

\section{Introduction}

Snow and its properties (e.g. snow cover extent, snow depth, snowfall, snow water equivalent) play an important role in the global energy and water cycles, particularly at high elevations. Snow exerts a strong control on regional climate and energy balance due to its high albedo and high emissivity as well as low thermal conductivity [Brown and Mote, 2009; Groisman et al., 1994a; Groisman et al., 1994b; S C Kang et al., 2010; X Li et al., 2008; C D Xiao et al., 2007; C D Xiao et al., 2008; M Yang et al., 2010; M Yang et al., 2019; Yasunari, 2007; Zuo et al., 2011; Zuo et al., 2012]. The presence of snow increases surface albedo and reduces absorbed shortwave radiation. When snow melts it increases the latent heat sink at the expense of sensible heat, resulting in regional cooling over snow-covered regions. Moreover, snow is also a critical component of the hydrological system in middle/high altitude regions, providing an reservoir of water and acting as a buffer controlling river discharge and associated environmental processes [Barnett et al., 2005; Groisman et al., 1994a; Groisman et al., 1994b; Huang et al., 2016; IPCC, 2013; X Li et al., 2008; Qin et al., 2014; Räisänen, 2008; T Zhang, 2005; Zuo et al., 2012]. The thickness and melting of snow can affect soil temperature, associated soil freezing and thawing processes [M Yang et al., 2010; M Yang et al., 2019] and soil moisture regimes, which in turn affects biochemical cycles [Ren et al., 2019; Seneviratne et al., 2010].

The Tibetan Plateau (TP), averaging over $4000 \mathrm{~m}$ above sea level, is called the "Third Pole" and contains the largest volume of cryospheric extent (e.g. snow, ice, glacier, 
permafrost) outside the polar regions [Immerzeel and Bierkens, 2012; S C Kang et al., 2010; X Liu and Chen, 2000; Qin et al., 2006; J. Qiu, 2008; Jane Qiu, 2013; 2016; K Yang et al., 2011; $T$ Yao et al., 2019]. According to the Fifth Assessment Report of the Intergovernmental Panel on Climate Change [IPCC, 2013], global mean surface temperature shows a warming of $0.85^{\circ} \mathrm{C}$ during $1880-2012$. However, the TP has warmed much more rapidly. In situ observations, reanalyses and climate models show a clear amplification of the warming rate over the TP in recent decades [T Yao et al., 2019; You et al., 2016; You et al., 2019]. For example, annual warming rate over the TP during 1961-2013 is measured at $0.3^{\circ} \mathrm{C}$ decade $^{-1}$ [You et al., 2017; You et al., 2011; You et al., 2016], around twice the global rate for the same period [D Chen et al., 2015; S C Kang et al., 2010; X Liu and Chen, 2000]. Although snow over the TP is currently a vital water source for all of China, it is an extremely sensitive element to warming $[J$ Gao et al., 2019; $T$ Yao et al., 2012; T Yao et al., 2015; T Yao et al., 2019]. Under the background of global warming, snow cover is anticipated to decrease being controlled by the temperature threshold of $0^{\circ} \mathrm{C}$ [Brown, 2000; Brown and Mote, 2009; IPCC, 2013; Sun et al., 2018; Vuille et al., 2018; Vuille et al., 2008]. In addition to having consequences for hydrological and biological processes, snow cover also acts as a control on broad climate change and climate systems over the TP and its surroundings through interactions with atmospheric circulation systems [Bao et al., 2018; W Li et al., 2018b; Shen et al., 2015; R Zhang et al., 2016].

Although much research has examined changes in snow characteristics and subsequent effects over the TP and its surroundings, there are still uncertainties and limitations. In 
this study, we review recent studies and attempt to quantify recent and future changes in snow cover. The climatology of snow cover over the TP is summarized in section 2 . In section 3, physical factors contributing to snow cover variability over the TP are discussed. The broad consequences of snow cover over the TP and its influence on climate systems are discussed in section 4. Section 5 summarizes some new perspectives on snow cover over the TP and Section 6 concisely summarizes the way forward.

\section{Recent climate change of snow cover over the TP}

\subsection{Relationship between snow cover over the TP and wider Eurasia}

Snow cover over the TP has often been examined in tandem with that over the broad Eurasian continent, since the TP is usually considered to be a sub-section of the Eurasian sector [Clark and Serreze, 2000; Zhong et al., 2018]. Snow cover over the high latitudes of Eurasia has decreased significantly over the last 40 years and the rate of decrease has accelerated [Brown and Robinson, 2011]. In March, Eurasia has shown among the strongest snow cover reductions for the Northern Hemisphere, declining by 0.8 million $\mathrm{km}^{2}$ per decade during $1970-2010$ (equating to a $7 \%$ decrease from pre1970 values) [Brown and Robinson, 2011]. More generally snow cover decreases in recent decades, consistent with Arctic amplification of warming [Dery and Brown, 2007; Ye and Wu, 2017; Ye et al., 2015; Yeo et al., 2017].

The snow cover over the TP is located in relatively low latitudes and on complex terrain and therefore has a unique climatology distinguished from Eurasian snow cover. For 
example, analysis of snow cover data from the National Oceanic and Atmospheric Administration (NOAA) [Bamzai, 2003; Bamzai and Shukla, 1999] shows that winter snow cover over western Eurasia has a negative relationship with Indian summer monsoon precipitation in the following year, but this relationship does not extend to the TP [C Wang et al., 2017a]. The correlation between winter/spring snow cover over the TP and that over Eurasia as a whole is negative [C Wang et al., 2017a; $Z W W u$ et al., 2016].

\subsection{Climatology of snow cover based on observation and remote sensing}

Table 1 lists main results of different studies which have examined the climatology and trends of snow cover over the TP based on in situ observations and remote sensing. There are several data sources available including: observation stations, satellite observations by NOAA, SMMR (Scanning Multichannel Microwave Radiometer) by NASA (National Aeronautics and Space Administration), and EOS/MODIS (Earth Observation System/Moderate Resolution Imaging Spectroradiometer) satellite retrieval products [Che et al., 2017; Dai et al., 2017; Qin et al., 2006; M Yang et al., 2019; You et al., 2011; G Zhang et al., 2012]. Each data source has its own limitations. There are more than 100 meteorological stations over the TP supported by the China Meteorological Administration, but most are located in the eastern and central TP (Figure 1). Most snow cover records started around the mid-1950s. In the high mountains with extensive snow, especially over the western TP, there are few or even no stations and thus the regional representativeness of observation data is limited $[C D$

Xiao et al., 2007; C D Xiao et al., 2008; M Yang et al., 2010; M Yang et al., 2019]. Due 
to its high resolution in both space and time, MODIS data has a great potential for monitoring snow cover change in regions with complex terrain [Che et al., 2017; Dai et al., 2017; S Wang, 2017; W Wang et al., 2015], and has already been used extensively to examine the distribution and seasonal changes of snow cover over the TP $[X$ Wang et al., 2017b; J Yang et al., 2015]. At large spatial scales, passive microwave remote sensing data is the most efficient way to monitor temporal and spatial variations in snow. However, snow cover products derived from passive microwave remote sensing show large uncertainties over the TP primarily occurring in the northwest and southeast areas with low ground temperature, and the overall accuracy in identifying presence/absence of snow cover is $66.7 \%$ [Dai et al., 2017].

Climatological studies of snow cover based on MODIS show large spatio-temporal heterogeneity over the TP (Table 1). The most persistent snow is located on the southern and western edges where precipitation from the Indian monsoon spills over the frontier ranges such as the Himalayas [Pu and Xu, 2009; Pu et al., 2007]. This corresponds well with the highest mountains, including the Kunlun, Karakoram, Himalaya, Qilian, Tanggula, and Hengduan chains [Pu and Xu, 2009; Pu et al., 2007; Qin et al., 2006]. The combined areas of Karakoram and Kunlun contain some of the most heavily glaciated regions in the world. In the southeast of the TP, snow cover is also relatively frequent because moist air is channeled up the Yarlung Zangbo Valley from the south. In contrast, due to large scale shielding by the Himalaya and Karakoram mountains, most of the interior of the TP has infrequent snow cover, even in winter at elevations above $4000 \mathrm{~m}$. In summer, there is scattered patchy snow cover in the high elevations 
regions along the Himalayas, Karakoram, and Kunlun ranges [Pu and Xu, 2009; Pu et al., 2007], and in some areas snow cover is almost as frequent in summer as in winter. Thus, the spatial distribution of snow cover is strongly controlled by the interactions between complex terrains and available moisture sources [Pu and Xu, 2009; Pu et al., 2007]. Except in the western TP where snow cover persists all year in favored locations, studies combining remote sensing and in situ observations have highlighted three broader areas of persistent snow cover: a) a southern center located on the north slope of the Himalayas; b) the eastern Tanggula and Nyenchen Tanglha Mountains; and c) the Amne Machin and Bayan Har Mountains in the eastern TP [Pu and Xu, 2009; Pu et al., 2007; W Xu et al., 2017; J Yang et al., 2015]. Obvious seasonal patterns in snow cover emerge for most of the TP, and with the exception of the aforementioned regions of permanent snow cover in the western TP, snow cover is mostly confined to October to May [Tan et al., 2019; Tang et al., 2013].

\subsection{Inter-annual variability and trends of snow cover}

The strongest inter-annual variations of snow cover occur in the mid-winter period. Trends in snow cover over the TP for the last 40-50 years display remarkable regional and seasonal differences (Table 1). Several studies have examined spatial and temporal variations of snow cover over the TP using MODIS data during 2000-2006 [Pu and Xu, 2009; Pu et al., 2007], 2001-2010 [G Zhang et al., 2012], 2001-2011 [Tang et al., 2013], 2001-2014 [C Li et al., 2018a], and 2000-2015 [X Wang et al., 2017b]. Over these short periods, snow cover over the TP does not generally show a significant decrease [Huang et al., 2016; Huang et al., 2017; X Wang et al., 2017b]; however, it exhibits a relatively 
large interannual variability [Z Wang et al., 2019]. As MODIS data is only available for a short period, in situ observations have also been examined to investigate snow cover trends, but different studies based on different stations/periods have led to contradicting results [WXu et al., 2017; $M$ Yang et al., 2019].

Trends of snow cover/depth over the TP are also generally very sensitive to period of study, especially if the period starts with a very high or very low condition. Figure 2 shows the variation of annual mean snow depth, temperature and precipitation based on the 108 observation stations over the TP during 1961-2014. It is noted that most observations are located over the central and eastern TP (Figure 1). Daily snow cover at 60 stations over the eastern TP appears to increase during 1957-1992 [P $J \mathrm{Li}, 1996$ ], consistent with increased trend after the mid-1970s based on 17 stations during 19621993 [Y S Zhang et al., 2004], and increased rate during the strong warming of the 1980s/1990s [Qin et al., 2006]. Overall, in situ observations and satellite data over the TP [Qin et al., 2006] show a weak increasing trend in snow cover between 1951-1997 but a slight decreasing trend between 1997 to 2012 [Shen et al., 2015], which is consistent with Figure 2. This is also reflected by a study of snow depth variation based on 69 stations above $2000 \mathrm{~m}$ over the TP during 1961-2005, that found snow depth over the TP has increased at the rate of $0.32 \mathrm{~mm} \mathrm{decade}^{-1}$ from 1961 to 1990 , but decreased at the rate of $-1.80 \mathrm{~mm} \mathrm{decade}^{-1}$ between 1991 and 2005 [You et al., 2011]. There have also been changes in the seasonality of snow cover over the TP, but results depend on station selection, study period and methods of calculation. In winter, the number of snow cover days over the TP during 1961-2013 increases significantly before 
1996 but decreases after 1996 [Bao et al., 2018]. Another study using 103 stations during 1961-2010 shows a very weak negative trend for the number of snow cover days in spring and winter, and has a significant decrease in summer and autumn [ $W X u$ et al., 2017]. Based on snow cover data from the National Snow and Ice Data Center (NSIDC) for 1979-2006, a significant decreasing trend over snow cover is observed in the western TP in summer and autumn, and over the southern TP in all seasons. In contrast, a significant increasing trend of snow cover is identified in the central and eastern TP in autumn, winter, and spring [Z Wang et al., 2018b; Z Wang et al., 2017c; Z Wang et al., 2019].

\subsection{Future changes of snow cover under different emission scenarios}

The response of snow cover to global warming will vary with latitude and elevation, with a potential for increased accumulation in high latitudes/elevations in the short term [Groisman et al., 1994a; Räisänen, 2008]. A warmer climate will influence snowfall and in turn snowpack development and the timing and amount of snowmelt [Barnett et al., 2005; Huning and AghaKouchak, 2018; Vuille et al., 2018; Vuille et al., 2008], would effectively enhance the seasonal hydrological cycle and increase the occurrence of outburst floods over the TP [Benn et al., 2012; Sun et al., 2018; M Yang et al., 2019; T Yao et al., 2012; $T$ Yao et al., 2015; $T$ Yao et al., 2019].

Projections of snow cover changes over the TP are often made using global climate models (GCMs) [Rangwala et al., 2010a; Wei and Dong, 2015; M Yang et al., 2019] and/or high-resolution regional climate models (RCMs) [Ji and Kang, 2013; Ménégoz et al., 2013; Shi et al., 2011]. For example, the fifth phase of the Coupled Model Inter- 
comparison Project (CMIP5) GCM projections over the TP indicate a continued warming throughout the $21^{\text {st }}$ century, with enhanced temperature increase at higher elevations [Dimri et al., 2016; Furlani and Ninfo, 2015; Hertig et al., 2015; Z Li et al., 2019b; Ren et al., 2019; You et al., 2016; You et al., 2019]. Although CMIP5 GCMs often capture the main characteristics of the observed the Northern Hemisphere snow cover in spring (i.e. its broad spatial distribution) they often overestimate mean snow cover in areas of complex terrain such as the TP [X Zhu and Dong, 2013]. Snow is poorly simulated by most CMIP5 GCMs due to limitations in parameterization schemes and in our understanding of physical processes, particularly clouds and localized convection [X Qu and Hall, 2006; Wei and Dong, 2015]. Regional annual mean snow depth over the TP from CMIP5 models under different RCP scenarios (representative concentration pathways) generally decreases in the late $21^{\text {st }}$ century. The trends of regional annual mean snow depth over the TP under RCP2.6, RCP4.5, and RCP8.5 are approximately $-0.06,-0.06$, and $-0.07 \mathrm{~cm}$ year $^{-1}$, respectively [Wei and Dong, 2015]. Mean snow cover duration over the TP under RCP4.5 is shortened by 10-20 and 2040 days during the middle (2040-2059) and end (2080-2099) of the $21^{\text {st }}$ century respectively [Ji and Kang, 2013].

A number of modeling studies have specifically focused on the TP region. The GISSAOM (Goddard Institute for Space Studies-Atmosphere Ocean Model, NASA) GCM indicates a continuous reduction in snow cover during spring and summer at higher elevations which accelerates surface warming through the snow-albedo effect [Rangwala et al., 2010a]. RCM has been shown to reasonably simulate both extent and 
duration of snow cover in the Himalayas [Ménégoz et al., 2013]. A high resolution RCM (Abdus Salam International Centre for Theoretical Physics) has been shown to successfully simulate current days of snow cover, snow depth, and the beginning and ending dates of snow cover in China (including the TP), and therefore has been used to estimate future snow cover changes [Shi et al., 2011; Zhou et al., 2018]. The model indicates that in the $21^{\text {st }}$ century under RCP4.5 and RCP8.5 scenarios, both snow days and snow cover over the TP will decrease whereas the starting/ending date will be delayed/advanced [D Chen et al., 2015; Ji and Kang, 2013; Shi et al., 2011].

\section{Physical mechanisms controlling snow cover over the TP}

\subsection{Temperature and precipitation as main controlling factors}

Figure 3 shows the factors which contribute to variation of snow cover over the TP. It is clear that snow cover is influenced by both precipitation and temperature, which in turn vary with elevation and season (Figure 3). During recent decades, observations indicate rapid warming and wetting over the TP, and snow over the TP exhibits positive correlations with both precipitation and temperature before the 1980s (Figure 2). Due to complex topography and varied climate regimes over the TP, the relative importance of temperature versus precipitation shifts across space. At higher elevations temperature is the most significant control, and it is less important in lower regions [ $W$ Wang et al., 2015; X Wang et al., 2017b; Z Wang et al., 2017c]. This is inconsistent with the controls of snow cover over Switzerland, where temperature/precipitation is the major factor below/above a threshold elevation [Morán-Tejeda et al., 2013]. It has been suggested 
that both temperature and precipitation become more influential controls as elevation increases in China [X Wang et al., 2017b].

Decreases in snowfall and increases in temperature and liquid precipitation are the main reasons for the snow cover decrease over the TP during 2001-2014. At high elevations the positive feedback of snowfall on snow cover becomes more important because there melting occurs. At the same time, any negative feedback effects of precipitation and temperature are also increased [Huang et al., 2016; Huang et al., 2017]. This can be explained because maximum snowfall amounts are usually recorded at temperatures between $1^{\circ} \mathrm{C}$ and $2{ }^{\circ} \mathrm{C}$. Above/below this threshold snowfall usually decreases/increases with increased warming [Deng et al., 2017], suggesting the response of snowfall to temperature change is depends on the magnitude of temperature. Additionally in winter, changes of snow cover extent are more susceptible to precipitation changes, whereas in summer temperature becomes a crucial factor because of frequent melt between snowfall events [ $W$ Wang et al., 2015; X Wang et al., 2017b; Z Wang et al., 2017c]. It has been estimated that about one-half to two-thirds of the inter-annual variability in snow cover can be explained by precipitation and temperature combined [ $W$ Xu et al., 2017]. Thus, there remains an important challenge in understanding and interpreting the observed changes in snow cover over the TP due to the competing effects of temperature and precipitation.

\subsection{Influence of synoptic conditions: Arctic Oscillation (AO)}

Snow cover over the TP is controlled by atmospheric circulation as indicated by indices such as the Arctic Oscillation (AO) [Bamzai, 2003; Cohen et al., 2012; Shaman and 
Tziperman, 2005; You et al., 2011] (Figure 3). The AO exerts its most significant control in winter and spring over the TP [Bamzai, 2003; Yeo et al., 2017]. For example, modulated by the positive AO, weakening of the Lake Baikal ridge pushes cold air southwards which meets with warm and humid air from low-latitudes over the eastern TP, conducive to more snowfall and greater snow over this region [Bao et al., 2018]. During 1961-2005, a positive relationship between mean snow depth over the TP and winter AO index was observed [You et al., 2011]. During positive AO years, the Asian subtropical westerly jet intensified, the Indian-Myanmar trough deepened, and a cyclonic circulation near Lake Baikal intensified, enhancing ascending motion and favoring greater snowfall over the TP [Xin et al., 2010; You et al., 2011; Yu and Zhou, 2004].

The AO and therefore the snow depth over the TP experience an inter-decadal regime shift in the late 1970s. Before the late 1970s (negative AO) snow depth over the TP is relatively high/low in autumn/winter. Since the early 1980s (positive AO) snow depth over the TP is decreased/increased in autumn/winter [L̈̈ et al., 2008]. In winter, the downward propagation of Rossby waves associated with the positive AO phase amplifies the atmospheric circulation in the mid-latitude troposphere, and can lead to subsequent abnormal increases of snow depth over the TP [Lü et al., 2008].

\subsection{Influences of westerly jet streams on snow cover}

Another important control of snow cover over the TP is the mid-latitude westerly jet stream, particularly in the northern and western TP [Mao, 2010; Mölg et al., 2014;

Schiemann et al., 2009]. Although the non-monsoon-dominated areas such as the 
Karakorum receive much of their winter snowfall from storms embedded in the westerly jet stream, it has also been more recently agreed that westerlies also drive snow variability in monsoon-dominated regions further south and east. For example it is shown that large-scale westerly waves control tropospheric flow strength and explain $73 \%$ of the inter-annual mass balance variability of Zhadang Glacier in the central TP [Mölg et al., 2014].

In addition to the mid-latitude westerlies, the sub-tropical westerly jet is also important. Much of the plateau is located between two maxima in this jet, i.e., downstream of the exit region of the North Africa-Arabian jet and upstream of the entrance region of the East Asian jet [Bao and You, 2019]. This recent study shows that snow depth in late winter and spring (February-April) over the TP is controlled by variations in intensity and meridional shifts of the westerly jet. Particularly in spring, the jet can form a split flow, with maxima classified as the North TP jet and the South TP jet, and shifts between the North TP jet and the South TP jet can favor significant cooling and increased precipitation, thus promoting snowfall and snow accumulation over the TP $[$ Bao and You, 2019]. Over long time scales from November to the subsequent February, the southwestward shift of the upper tropospheric westerly jet may have favored the development of more intense surface cyclones over the TP, which is favorable for heavier snowfall, leading to an increase in snow depth over the TP [Mao, 2010].

\subsection{Ocean-atmosphere coupling systems remotely modulate snow cover}

Inter-annual variability of snow cover over the TP can also be modulated by oceanatmosphere coupling systems, such as El Nino/Southern Oscillation (ENSO), Indian 
Ocean dipole, sea surface temperatures (SST), North Atlantic Oscillation (NAO) and Southern Annular Mode [Dou and Wu, 2018; Shaman and Tziperman, 2005; 2007; Y Wang and Xu, 2018; Z Wang et al., 2019; $J$ Wu and Wu, 2019; $R$ Wu and Kirtman, 2007; Yuan et al., 2009; Yuan et al., 2012]. Shaman and Tziperman [2005] found that winter ENSO conditions in the central Pacific modify winter storm activity and resultant snowfall over the TP by the development of quasi-stationary barotropic Rossby waves in the troposphere with a north-eastward group velocity. Because snow cover variations over the eastern and western TP are essentially decoupled, SSTs in the eastern equatorial Pacific (east of $130^{\circ} \mathrm{W}$ ) are positively correlated with snow depth over the western TP in winter, but there is no correlations over eastern regions $[X X u$ and Wang, 2016]. Yuan et al. [2009] suggested that the influence of ENSO on snow cover over the TP in early winter, spring and early summer is dependent on the Indian Ocean dipole. In early winters of pure positive Indian Ocean dipole years with no co-occurrence of El Niño, anomalous diabatic heating over the tropical Indian Ocean encourages a baroclinic response in the tropics, enabling the transport of moisture cyclonically from the northern Indian Ocean toward the TP [Yuan et al., 2012].

Few studies have focused on the variability of snow cover over the TP in the boreal summer [Jin et al., 2018]. In a recent study, the Southern Annular Mode index in May exhibits a significant positive relationship with the inter-annual variations of snow cover in the western TP during the following boreal summer [Dou and $W u, 2018$ ]. 


\subsection{Impacts of snow cover on the East Asian Summer Monsoon (EASM)}

Snow cover over the TP has a close relationship with the atmospheric circulation in mid-latitudes and other circulation systems such as the East Asian Summer Monsoon (EASM) [L Chen and Wu, 2000; Q Chen et al., 2000b; Duan et al., 2018; Duan et al., 2014; Luo, 1995; Z Xiao and Duan, 2016; S Zhang and Tao, 2001]. Many physical mechanisms for the impact of snow cover over the TP on the EASM have been proposed [Y F Qian et al., 2003; Z Xiao and Duan, 2016; S Zhang and Tao, 2001; Y S Zhang et al., 2004; Y S Zhang and Ma, 2018; Y Zhu and Ding, 2007]. Figure 4 shows possible mechanisms which control this relationship. For example, it has been suggested that more snow cover will reduce the tropospheric land-sea temperature contrast and weaken the EASM in the following summer. More (less) snow cover over the TP leads to weak (strong) surface heating in spring and summer, and weak (strong) upward motion associated with strong (weak) westerly jet stream. This is therefore unfavorable (favorable) for transporting sensible heat from near-surface to upper atmospheric layers which leads to tropospheric heating and subsequent low (high) tropospheric temperature surrounding the TP. The resultant weak (strong) meridional tropospheric temperature gradient south of the TP creates a weak (strong) EASM [S Zhang and Tao, 2001].

Thus an increase in snow cover over the TP can both delay the onset and weaken the intensity of the EASM, resulting in drier conditions in southern China, but wetter conditions in the Yangtze and Huaihe River basins [Y F Qian et al., 2003]. Specifically, positive (negative) snow cover anomalies over the TP in spring are followed by later 
(earlier) onset of the EASM [Pu and $X u, 2009]$. Excessive snowmelt over the TP can cool surface temperatures and provide sufficient moisture which also causes a more northwestward extension of the western Pacific subtropical high in the subsequent summer [Y S Zhang et al., 2004]. Excessive summer snow cover over the western TP can suppress local convection but in turn benefit upward motion elsewhere, especially further south over the north Indian Ocean via a meridional circulation system [G Liu et al., 2014a; G Liu et al., 2014b]. Recently it has been revealed that the western TP and the Himalaya are critical regions in this regard, and snow cover in these regions can also influence the EASM by modulating eastward-propagating synoptic disturbances generated over the TP [Z Xiao and Duan, 2016].

\subsection{Snow cover and subsequent EASM precipitation}

Figure 5 shows a schematic diagram of physical processes that link snow cover over the TP and EASM precipitation. Winter and spring snow cover over the TP plays an important role in influencing subsequent EASM precipitation [Tao and Ding, 1981; C Wang et al., 2017a; R N Zhang et al., 2017; Y S Zhang et al., 2004; Y Zhu et al., 2015]. EASM precipitation has two typical spatial patterns on both inter-annual and interdecadal timescales, i.e. the triple pattern and the North/South reversed-phase pattern [Duan et al., 2018; Duan et al., 2014]. A clear negative relationship exists, modulated by the quasi-biennial oscillation, between winter snow cover over the TP and subsequent summer precipitation in parts of far northern China and southern China $[L$ Chen and $W u, 2000]$. Furthermore, a long-term decadal decrease of winter snow cover over the TP is in good correspondence with a remarkable transition from drought to a 
wet period at the end of the 1970s in these areas [ $L$ Chen and Wu, 2000; Q Chen et al., 2000a; $Q$ Chen et al., 2000b]. In contrast, there is a strong positive correlation between winter snow cover and subsequent summer precipitation over the middle and lower reaches of the Yangtze River valley, both in observational data and numerical simulations [Q Chen et al., 2000a; $Q$ Chen et al., 2000b; $R$ Wu and Kirtman, 2007; TW Wu and Qian, 2003]. For example, snow cover over the TP in preceding winter and spring can be regarded as a key prediction in EASM precipitation, and a remarkable case of application is the successful seasonal prediction of 1998 unprecedented flood in the Yangtze River [CMA, 1998]. Spring snow cover over the TP is positively correlated with subsequent summer $500 \mathrm{hPa}$ geopotential height over the western Pacific and this was demonstrated to increase summer precipitation in the Huaihe River valley during 2002-2010 [Y Zhu et al., 2015]. There is evidences that the interdecadal increase of snow cover over the TP in spring causes a more northwestward extension of the western Pacific subtropical high in the subsequent summer, resulting in a wetter summer precipitation over the Yangtze River valley and a dryer one in the southeast coast of China [L Chen and Wu, 2000; Ding et al., 2009; R Wu et al., 2010; Y S Zhang et al., 2004].

More recently, it has been found that heavier snow cover over the southern TP leads to more precipitation in the Yangtze River basin and northeastern China, but less precipitation in southern China (Figure 5). Heavier snow cover over the northern TP on the other hand, results in enhanced precipitation in southeastern and northern China but weakened precipitation in the Yangtze River basin [C Wang et al., 2017a]. It has 
also been shown that snow cover in western/southern parts of the TP influences EASM precipitation through different pathways, inducing anomalous cooling in the overlying atmospheric column [Z Wang et al., 2018b].

Snow cover in summer over the TP and its effects on climate variability are often overlooked [G Liu et al., 2014a; G Liu et al., 2014b; Z W Wu et al., 2011]. Summer snow cover is significantly positively correlated with simultaneous precipitation over the Meiyu-Baiu region on the inter-annual time scale, suggesting that snow cover could be regarded as an important additional factor in the forecasting of precipitation in that region [G Liu et al., 2014a; G Liu et al., 2014b]. Finally pollution deposition on snowpack (in particular black carbon) over the TP has been shown to increase diabatic heating over the TP, resulting in anomalously wet, dry, and slightly wet patterns over southern China, the Yangtze River basin, and northern China, respectively [Y Qian et al., 2011].

\subsection{Impacts of snow cover on the South Asian Summer Monsoon (SASM) and its} precipitation

The South Asian Summer Monsoon (SASM) is also a significant part of the Asian summer monsoon system, which has long been thought to be influenced by snow cover over the TP [Brown and Mote, 2009; L Chen and Wu, 2000; Cohen and Rind, 1991; Duan et al., 2018; Duan et al., 2014; Dugam et al., 2009; Fasullo, 2004; Groisman et al., 1994b]. More than a century ago, Blanford [1884] found a negative relationship between Himalayan winter snow accumulation and subsequent SASM precipitation. Based on data during 1876-1908, Walker [1910] confirmed the inverse relationship 
between Himalayan snow in winter/spring and the SASM. The negative relationship [Blanford, 1884; Walker, 1990] was re-examined and verified using NOAA satellite snow cover data [Dery and Brown, 2007; Dey and Kumar, 1983]. In recent years, more studies have re-examined this relationship [Robock et al., 2003; Zhao and Moore, 2002; 2004; 2006], which is associated with both snow-albedo effects and hydrological effects [Yasunari, 2007; Yasunari et al., 1991]. The snow-albedo effect means that excessive snow cover reduces solar radiation absorbed at the surface which decreases surface temperature, thus weakening the SASM. The hydrological effect occurs when melting of an anomalous snow cover results in increased latent heat flux, reduced sensible heat flux, cooler surface and higher surface pressure [Yasunari, 2007; Yasunari et al., 1991]. Recent studies have suggested that the hydrological effects are in fact dominant and far more important than any direct thermal or albedo effect [Barnett et al., 2005; Cohen and Rind, 1991; L Xu and Dirmeyer, 2012].

Increased winter snow cover over the TP leads to a weakened Somali jet, a weaker Indian monsoon trough and associated south-west flow, resulting in a reduced SASM [Fan et al., 1997; Y S Zhang et al., 2004]. Anomalous snow cover over the TP increases the meridional tropospheric temperature gradient in winter/spring and also delays its reversal in late spring which is the trigger for the SASM onset. Hydrological effects which cool the surface have been shown to delay the monsoon onset by about 8 days on average [Halder and Dirmeyer, 2016; Senan et al., 2016].

It is clear however that the widely discussed negative relationship between Himalayan snow and the strength of the subsequent SASM does not always hold. No significant 
relationship between snow cover over the TP and SASM precipitation was found during 1973-1994 [Bamzai and Shukla, 1999]. Moreover, a positive correlation between snow cover and SASM precipitation was detected during 1870-2000 [Robock et al., 2003], opposite to that of Blanford [1884]. Based on a 196-year record of snow accumulation from a Himalayan ice core, from the 1940s onwards a decreasing trend in snow accumulation is associated with a long-term weakening of the trade winds over the Pacific Ocean, but this does not result in any systematic changes in SASM precipitation [Zhao and Moore, 2006].

Strikingly, the well-documented negative relationship between snow cover over the TP and SASM precipitation seems to have changed to a positive relationship in recent decades [Kripalani et al., 2003; Zhao and Moore, 2002; 2004]. For example, an eastwest dipole-like correlation pattern between snow cover over the TP and SASM precipitation changed sign around 1985[Zhao and Moore, 2004]. Controversially, observed changes in snow cover extent/depth due to global warming may be a possible cause for the weakening relationship between snow cover and SASM precipitation [Kripalani et al., 2003]. It has also been suggested that the relationship between snow cover and SASM precipitation only exists during years with strong positive AO [Robock et al., 2003] and the existence of the Blanford [1884] mechanism only occurs when the influence of the land surface is not overwhelmed by ENSO [Fasullo, 2004].

\subsection{Impacts of snow cover on other climate variables}

Snow cover plays a strong role in controlling other parts of the climate system [Lin and Wu, 2011; 2012; M Yang et al., 2019]. For example, the thickness of snow cover can 
affect soil temperature, soil freeze-thaw cycles, and permafrost. More snow will reduce frost penetration and provide warmer soil temperatures overall as well as a more conservative climate at ground level. Melting snow influences carbon exchange between atmosphere and ground and hydrological/biochemical cycles over the TP $[M$ Yang et al., 2010; $M$ Yang et al., 2019; T Zhang, 2005]. In years with positive snow anomalies over the TP, soil moisture is increased well into the summer, and the surface temperature is stabilized and then reduced because of the snowmelt process. Much energy is used to melt the snow, altering moisture and energy partitioning at the surface and fluxes from surface to atmosphere [Y F Qian et al., 2003].

Snow melting is a major source of river runoff in many mountain basins over the TP, especially in the many endorheic basins, thus impacting ecosystems, irrigation, agriculture and water resources in the densely populated downstream areas [C Li et al., 2018a; Z Li et al., 2019b; T Wang et al., 2013; W Wang et al., 2015; X Wang et al., 2017b]. Spring runoff from extensive snowpack can minimize spring/summer drought in otherwise arid regions, and be beneficial for summer vegetation growth [Qin et al., 2006]. On the other hand, decreases of snow cover fraction over the TP (2000-2011) during January-April have caused the simultaneous Normalized Difference Vegetation Index (NDVI) to rise, associated with an advance in spring phenology and earlier snow melting [T Wang et al., 2013].

Finally, reduced (excessive) snow cover over the TP can encourage an upper-level anomalous anticyclone (cyclone) over the TP and eastern China, and lead to a westwards extension (eastwards withdrawal) and enhancing (weakening) of the South 
Asian High over the tropical oceans, which in turn contributes to the variability of convection within the Madden-Julian Oscillation [Lyu et al., 2018]. There have even been links between winter snow cover over the TP and typhoons in the Western Pacific during the following summer. Increased winter snow cover over the TP leads to a reduced surface sensible heat flux lasting well into spring and early summer, which has been proposed to lead to a reduced number of land-falling typhoons in China in the following summer/autumn [Xie et al., 2005].

\section{Research gaps and emerging issues related to snow cover over the TP}

\subsection{How frequent are snow avalanches over the TP?}

Avalanches, whereby large quantities of snow could bury villages and cause fatalities, are one of the most serious hazards in late winter and spring over the TP, with March and April being the two most hazardous months. Complex terrain with steep slopes means that much of the TP is regarded as high risk, especially in the south and east where snow falls can be heavy [Dong et al., 2001; Qin et al., 2018; T T Zhang et al., 2014]. The spatial distribution of avalanches shows the largest frequency in central areas, east of the Bayankalashan mountains and on the southeastern edge of the TP [Dong et al., 2001]. In recent decades, both the frequency of avalanches and the number of stations show an increased event of avalanches. While more reliable reporting could partially explain the observed increase, from a physical viewpoint, inter-annual variations in the subtropical high anomalies in the West Pacific Ocean is one of the main factors for the observed increase in their frequency [Dong et al., 2001; T T Zhang 
et al., 2014]. Station records and satellites differ in their ability to capture extreme high snow depths which are the precursor for avalanches [Qin et al., 2006; Qin et al., 2018; M Yang et al., 2019]. Because of these differences, no consensus has yet been reached on whether avalanches have overall increased. It is also noted that snow depth alone is not the only control of avalanche occurrence, so more holistic frameworks with a wide range of datasets must be applied to understand, model and predict avalanches.

\subsection{Do reanalyses, remote sensing and climate models capture similar patterns of}

\section{snow cover variation?}

The scarcity of surface observations over the TP, coupled with complex terrain, limits understanding of snow cover change, especially in the western regions. Only $0.1 \%$ of snow fields, glaciers and lakes over the TP have monitoring stations [M Yang et al., 2010; M Yang et al., 2019; T Yao et al., 2019; T D Yao et al., 2004]. Very few areas above 5000m over the TP have weather stations. Many studies therefore have compared the available stations with reanalyses and remote sensing products as well as climate model outputs over the TP [Y Gao et al., 2018; Pu and Xu, 2009; A Wang et al., 2018a; You et al., 2015]. For example, reanalyses perform poorly for snow cover trend analysis, and most reanalyses (NCEP1, NCEP2, CMAP1, CMAP2, ERA-Interim, ERA-40, GPCP, 20century, MERRA and CFSR) remain substantial disagreements and large discrepancies with observations due to differences in types of observations and assimilation techniques across datasets [You et al., 2015]. Remote sensing datasets such as MODIS have consistent spatial coverage to enable identification of spatial patterns of snow cover over the whole TP, but they are not available to examine long term trends 
551

552

553

554

555

556

557

due to the short time span (typically from 1980 or later) [Pu and Xu, 2009; Pu et al., 2007; Tang et al., 2013; Zhao and Moore, 2002]. Cloud contamination in remote sensing datasets is a severe issue in mountainous regions and the southeastern TP $[J$ Yang et al., 2015; Z Zhu and Woodcock, 2014]. The GCMs such as CMIP5 output are often too coarse to resolve local changes, and RCMs with dynamical downscaling are suggested to study snow cover over the TP [ J Gao et al., 2019; Y Gao et al., 2018; Ji and Kang, 2013; A Wang et al., 2018a; Wei and Dong, 2015]. Although reanalyses, remote sensing and climate models are used to study snow cover over the TP, the scientific community still has relatively little understanding of why such discrepancies arise among different datasets. More efforts should focus on objective evaluation of multiple datasets as a large number of studies rely on such simulations.

\subsection{Does the snow cover trend show elevation dependency?}

Many studies have suggested that recent warming has an elevation dependency both at global and regional scales [S C Kang et al., 2010; Pepin and Coauthors, 2015; You et al., 2016; You et al., 2019]. Over the TP, the largest warming rates (1950-2010 period) have occurred in winter/spring at elevations around 4000-5000m [Rangwala et al., 2010b], although warming rates are thought to decrease above that elevation [Y Gao et al., 2018; Pepin et al., 2019]. However, whether there is a widespread elevation dependency of snow cover trends over the TP is still unclear, primarily because of limited observations and studies specifically focused on this topic. Over High Mountain Asia, there is a strong relationship between elevation and snow water equivalent during 1987-2009, but the relationship is nonlinear [Smith and Bookhagen, 2018]. Over the TP, 
many of the most distinct decreases in snow cover appear in high elevation areas such as the Hengduan Mountains and the northern Karakorum-Kunlun mountains [T Wang et al., 2013; W Wang et al., 2015], which is consistent with trends derived from MODIS during 2001-2014 [C Li et al., 2018a].

There are clear relationships between elevation and mean snow cover start date (earlier at higher elevations), mean end date (later at higher elevations), and therefore snow cover duration (longer at higher elevation) over the TP during 1961-2010 [W Xu et al., 2017]. However, the correlation between snow water equivalent trend and elevation is variable. In some regions of high snow-water storage, the strongest snow water equivalent decreases are seen in mid-elevation zones, while the highest elevations show less changes [Smith and Bookhagen, 2018]. At present, it is not clear whether snow cover trends over the TP show robust elevation dependency, and the multiple factors controlling snow (i.e. precipitation, temperature, solar radiation, wind) influence the elevation dependency patterns, which need more in-depth research.

\subsection{How will snow cover respond to $1.5^{\circ} \mathrm{C}$ and $2^{\circ} \mathrm{C}$ mean global warming?}

In the Paris Agreement of 2015, 195 nations agreed upon the aim of 'holding the increase in global average temperature to well below $2^{\circ} \mathrm{C}$ above pre-industrial levels and pursuing efforts to limit the temperature increase to $1.5^{\circ} \mathrm{C}^{\prime}$ [UNFCCC, 2015]. Recent studies have therefore focused on changes in climate and in the frequency, intensity, and duration of extreme events as well as snow cover associated with $1.5^{\circ} \mathrm{C}$ and $2^{\circ} \mathrm{C}$ global warming [Biskaborn et al., 2019; J Gao et al., 2019; Kong and Wang, 2017; Y Li et al., 2019a; Russo et al., 2019; A Wang et al., 2018a]. Over High Mountain 
Asia, warmer and wetter winters are modelled at both $1.5^{\circ} \mathrm{C}$ and $2^{\circ} \mathrm{C}$ global warming targets, with a global temperature rise of $1.5^{\circ} \mathrm{C}$ leading to warming of $2.1 \pm 0.1^{\circ} \mathrm{C}$ in this region [Kraaijenbrink et al., 2017], which influence the variation of snow cover over the TP. Based on CMIP5 mean ensemble, the largest magnitude of changes in snow cover fraction over the western TP could be above 10\% [A Wang et al., 2018a], and the snow cover patterns do show distinct differences between $1.5^{\circ} \mathrm{C}$ and $2{ }^{\circ} \mathrm{C}$ global warming levels [Y Li et al., 2019a]. However, there are limited studies on future snow cover change over the TP and in particular the differences between warming of $1.5^{\circ} \mathrm{C}$ vs $2^{\circ} \mathrm{C}$. Given that the two scenarios will likely lead to different snow outcomes, more efforts should focus on the social-economic consequences of snow availability under different future warming levels.

\subsection{How does snow cover broadly influence climate extremes in China?}

Extreme events such as heat waves, extreme precipitation and droughts, exert a disproportionate influence on human health, natural systems, and the economy [IPCC, 2013]. Snowpack over the TP is viewed as a regulator which can influence climate extremes in China [Qin et al., 2006; Qin et al., 2018]. A recent study shows that snow cover over the TP explains more than $30 \%$ of the total variance of heat wave occurrence in the southern Europe and the north-eastern Asia region [ $Z$ W Wu et al., 2016]. The snow cover over the TP is correlated with summer heat wave frequency across China, which features an extremely high occurrence over northern China [Z WWu et al., 2012]. Snow cover over the TP is inversely proportionate to TP heating (more snow, less heating). When TP heating is stronger (weaker) than normal, the occurrence of extreme 
617 precipitation events in summer tends to be more (less) over the middle and lower 618 reaches of the Yangtze River valley. This is associated with the combined effects of the upper-level South Asian high and the western Pacific subtropical high [Ge et al., 2019]. Although it is acknowledged that climate extremes in China have been affected by both TP snow cover and SST anomalies, it is critical to distinguish between the two influences [ $Z$ Wang et al., 2018b; Z W Wu et al., 2012; Z W Wu et al., 2016; Z Xiao and Duan, 2016]. Several studies have proposed that snow cover is the more important factor for successful sub-seasonal to seasonal prediction of extremes [Robertson et al., to seasonal predictability of weather/climate extremes remains unresolved and more work is necessary to improve understanding through both observational and numerical studies.

\subsection{How does snow cover variation link to atmospheric pollutions?}

Deposition of atmospheric pollutant, here mainly referred to as light absorbing aerosols (e.g., black carbon, brown carbon and dust), can enhance snowmelt and contribute to reducing snow cover [Ramanathan et al., 2007], and should be regarded as one of the important physical mechanisms inducing snow cover variation over the TP $[J i, 2016$; snow/ice on glaciers over the TP are together responsible for a reduction in albedo of about $20 \%$, which contributes to their rapid melting [B Qu et al., 2014]. Based on a 
$0.1-0.5^{\circ} \mathrm{C}$ and causes a decrease of $5-25 \mathrm{~mm}$ in annual snow water equivalent over the western TP and the Pamir and Kunlun Mountains. Meanwhile, black carbon on snow results in a warming of $0.1-1.5^{\circ} \mathrm{C}$ and the loss of snow water equivalent exceeding 25mm in the western TP and the Himalayas [Ji, 2016; Ji et al., 2015; Ji et al., 2016]. Based on the snow samples and back trajectory analysis, the effect of black carbon and dust reduces the snow cover duration by 3 to 4 days over the TP [Y Zhang et al., 2018]. Recently, a coordinated monitoring network to link atmospheric pollution with cryospheric changes (APCC) within the TP has been proposed [S Kang et al., 2019]. In the future, more research programs will be supported within the framework of APCC in an attempt to understand the full interactions between snow cover variation and atmospheric pollution over the TP.

\section{Summary}

Snow cover over the TP has experienced uneven changes in recent decades. In this paper, we offer a comprehensive review of snow cover variation over the TP and its influence on the wider climate systems (see Figure 6). The results are summarized as follows:

(1) Snow cover over the TP is often considered to be the southward extent of Eurasian snow cover, and shares both similarities and differences with the broader continent. Snow cover over the TP has distinct seasonal and spatial signatures. The region with persistent snow cover is located in the southern and western edges in high elevation mountains $(>6000 \mathrm{~m})$, while snow is more variable in the eastern regions. Overall, the 
661

662

663

664

665

666

667

668

669

670

671

672

673

674

675

676

677

678

679

680

681

682

observed snow cover over the TP has shown a small increase from 1950s to the mid1990s, and a decreasing trend since mid-1990s. However, there is no widespread decline in snow cover over the TP in the last 15 years based on MODIS data. Continuous reduction in snow cover at higher elevations is projected by both GCMs and RCMs under RCP4.5 and RCP8.5 scenarios by the end of $21^{\text {st }}$ century, although most models overestimate mean snow cover in complex terrains.

(2) Snow cover over the TP shows distinct inter-annual and inter-decadal variability, but physical factors contributing to this variability are complex. Both precipitation and temperature vary in their relative importance with elevation and season. Both the AO and the westerly jet influence the atmospheric circulation in the troposphere, through their influences on the positioning of the India-Burma trough, subtropical westerly jet, and associated enhanced ascending motion. Additional ocean-atmosphere coupling, expressed through changes in ENSO, Indian Ocean dipole, SST, NAO and SAM also contributes to recent changes in snow cover over the TP. However, it is difficult to determine the relative contribution of each of these factors in controlling variability of snow cover over the TP.

(3) The impacts of snow cover over the TP on the EASM, SASM and associated precipitation are clear. Enhanced snow cover over the TP can delay the onset and weaken the intensity of the EASM, and has a strong influence on typical spatial patterns of EASM precipitation on both inter-annual and inter-decadal timescales. Snow cover over the western TP and the Himalayas is of particular importance. A clear relationship exists (modulated by the quasi-biennial oscillation) between winter snow cover and 
683

684

685

686

687

688

689

690

691

692

693

694

695

696

697

698

699

700

701

following summer precipitation in far northern China and parts of southern China. The well-documented negative relationship between snow cover and subsequent SASM precipitation seems to have changed to a positive relationship in recent decades. Snow cover over the TP induces a strong positive albedo feedback, and also causes indirect responses linked to insulation of frozen ground, moisture storage, and latent heat, which have widespread impacts on other climatic variables over the TP and its surroundings. (4) There are many unresolved issues concerning snow cover changes over the TP. No consensus has yet been reached on whether avalanches have increased or decreased over the past decades. Due to complex terrain and scarcity of surface observations over the TP, our understanding of snow cover change in the region, especially in the western TP is limited. Whether multiple reanalyses, remote sensing datasets and climate models capture the snow cover variability reliably over the TP is unclear. Whether trends of snow cover over the TP show an elevation dependency is still a source of debate. There are limited studies on the future changes of snow cover over the TP under $1.5^{\circ} \mathrm{C}$ vs $2^{\circ} \mathrm{C}$ mean global warming. Although it is known that snow cover over the TP regulates climate extremes in China, the underlying physical mechanisms are not well understood. Moreover, snow cover variation over the TP is influenced by deposition of atmospheric pollution However, the melting rates and physical mechanisms changing snow/ice melt still deserve more in-depth research.

Finally, due to high and steep terrains, conventional meteorological stations are very rare, and many mountains with extensive snow cover, especially in the western regions, are not sampled at all. Most meteorological stations are distributed in lower-altitude 
river valleys or plains where there is usually less snow. Remote sensing can measure snow, but the quality of remotely sensed data is often affected by clouds. Therefore, more in situ observations are critically needed to adequately study the spatial and temporal distribution of snow cover over the TP. There are substantial uncertainties in previous studies that have solely used in situ observations (or model simulations) to monitor long-term snow cover changes over the TP. More comparative studies using different types of data sources will likely improve reliability of snow analysis and their corresponding impacts over the TP region and beyond.

\section{Acknowledgments}

This study is supported by National Key R\&D Program of China (2017YFA0603804) and National Natural Science Foundation of China (41771069, 41971072 and 41911530187). We are very grateful to the anonymous reviewers for their constructive comments and thoughtful suggestions.

\section{References}

Bamzai, A. S. (2003), Relationship between snow cover variability and Arctic oscillation index on a hierarchy of time scales, International Journal of Climatology, 23(2), 131-142, doi:10.1002/joc. 854 .

Bamzai, A. S., and J. Shukla (1999), Relation between Eurasian Snow Cover, Snow Depth, and the Indian Summer Monsoon: An Observational Study, Journal of Climate, 12(10), 3117-3132. Bao, Y., and Q. You (2019), How do westerly jet streams regulate the winter snow depth over the Tibetan Plateau?, Climate Dynamics, 53, 353-370, doi:10.1007/s00382-018-4589-1.

Bao, Y., Q. You, and X. Xie (2018), Spatial-temporal variability of the snow depth over the QinghaiTibetan Plateau and the cause of its interannual variation, Plateau Meteorology (in Chinese), 37(4), 
899-910.

731 Barnett, T. P., J. C. Adam, and D. P. Lettenmaier (2005), Potential impacts of a warming climate on 732 water availability in snow-dominated regions, Nature, 438(7066), 303-309, 733 doi:10.1038/nature04141.

734 Benn, D. I., T. Bolch, K. Hands, J. Gulley, A. Luckman, L. I. Nicholson, D. Quincey, S. Thompson, 735 R. Toumi, and S. Wiseman (2012), Response of debris-covered glaciers in the Mount Everest region to recent warming, and implications for outburst flood hazards, Earth-Science Reviews, 114(1), 156174, doi:https://doi.org/10.1016/j.earscirev.2012.03.008.

Biskaborn, B. K., et al. (2019), Permafrost is warming at a global scale, Nature Communications, 10(1), 264, doi:10.1038/s41467-018-08240-4.

Blanford, H. F. (1884), On the externsion of the Himalaya snowfall with dry winds and seasons of drought in India, Proc. Roy. Soc. London, 37, 1-23.

Brown, R. D. (2000), Northern Hemisphere Snow Cover Variability and Change, 1915-97, Journal of Climate, 13(13), 2339-2355.

Brown, R. D., and P. W. Mote (2009), The Response of Northern Hemisphere Snow Cover to a Changing Climate, Journal of Climate, 22(8), 2124-2145, doi:10.1175/2008jcli2665.1.

Brown, R. D., and D. A. Robinson (2011), Northern Hemisphere spring snow cover variability and change over 1922-2010 including an assessment of uncertainty, The Cryosphere, 5(1), 219-229, doi:10.5194/tc-5-219-2011.

Che, T., X. Li, R. Jin, R. Armstrong, and T. Zhang (2017), Snow depth derived from passive microwave remote-sensing data in China, Annals of Glaciology, 49, 145-154, doi:10.3189/172756408787814690. Chen, D., et al. (2015), Assessment of past, present and future environmental changes on the Tibetan Plateau, Chinese Science Bulletin, 60(0023-074X), 3025. Chen, L., and R. Wu (2000), Interannual and decadal variations of snow cover over Qinghai-Xizang Plateau and their relationships to summer monsoon rainfall in China, Advances in Atmospheric Sciences, 17(1), 18-30, doi:10.1007/s00376-000-0040-7.

Chen, Q., B. Gao, W. Li, and Y. Liu (2000a), Studies on relationships among snow cover winter over the Tibetan Plateau and droughs/floods during Meiyu season in the middle and lower reaches of the Yangze river as well as atmosphere/ocean, Acta Geograph Sinica (in Chinese), 58(5), 582- 
761 Chen, Q., B. Gao, and Q. Zhang (2000b), Studies on Relation of Snow Cover over the Tibetan

762 Plateau in Winter to the Winter-Summer Monsoon Change, Chinese Journal of Atmospheric 763 Sciences (in Chinese), 24(4), 477-492.

764 Clark, M. P., and M. C. Serreze (2000), Effects of Variations in East Asian Snow Cover on 765 Modulating Atmospheric Circulation over the North Pacific Ocean, Journal of Climate, 13(20), $766 \quad 3700-3710$.

767 CMA, N. C. C. o. (1998), 98 Floods and climate anomalies in China Beijing: Meteorological 768 Publishing Press.

769 Cohen, J., J. C. Furtado, M. A. Barlow, V. A. Alexeev, and J. E. Cherry (2012), Arctic warming, 770 increasing snow cover and widespread boreal winter cooling, Environmental Research Letters, 7(1), 771 014007, doi:10.1088/1748-9326/7/1/014007.

772 Cohen, J., and D. Rind (1991), The Effect of Snow Cover on the Climate, Journal of Climate, 4(7), $773 \quad 689-706$.

774 Dai, L., T. Che, Y. Ding, and X. Hao (2017), Evaluation of snow cover and snow depth on the 775 Qinghai-Tibetan Plateau derived from passive microwave remote sensing, The Cryosphere, 11(4), 776 1933-1948, doi:10.5194/tc-11-1933-2017.

Deng, H., N. C. Pepin, and Y. Chen (2017), Changes of snowfall under warming in the Tibetan 778 Plateau, Journal of Geophysical Research: Atmospheres, 122(14), 7323-7341, doi:10.1002/2017JD026524.

780 Dery, S. J., and R. D. Brown (2007), Recent Northern Hemisphere snow cover extent trends and 781 implications for the snow-albedo feedback, Geophysical Research Letters, 34(22), L22504.

782 Dey, B., and O. S. R. U. B. Kumar (1983), Himalayan winter snow cover area and summer monsoon 783 rainfall over India, Journal of Geophysical Research: Oceans, 88(C9), 5471-5474.

784 Dimri, A. P., T. Yasunari, B. S. Kotlia, U. C. Mohanty, and D. R. Sikka (2016), Indian winter 785 monsoon: Present and past, Earth-Science Reviews, 163, 297-322.

787 China and its association with decreasing Asian summer monsoon. Part II: Possible causes, International Journal of Climatology, 29, 1926-1944.

789 Dong, W. J., Z. G. Wei, and L. J. Fan (2001), Climatic character analyese of snow disasters in east 
Qinghai-Xizang Plateau livestock farm, Plateau Meteorology (in Chinese), 20(4), 402-406.

Dou, J., and Z. Wu (2018), Southern Hemisphere Origins for Interannual Variations of Snow Cover over the Western Tibetan Plateau in Boreal Summer, Journal of Climate, 31(19), 7701-7718, doi:10.1175/JCLI-D-17-0327.1.

Duan, A., Xiao Zhixiang, and W. Ziqian. (2018), Impacts of the Tibetan Plateau winter/spring snow depth and surface heat source on Asian summer monsoon: A review, Chinese Journal of Atmospheric Sciences (in Chinese), 42(4), 755-766.

Duan, A., X. Zhixiang, W. Guoxiong, and W. Meirong (2014), Study Progress of the Influence of the Tibetan Plateau Winter and Spring Snow Depth on Asian Summer Monsoon, Meteorological and Environmental Sciences (in Chinese), 37(3), 94-101.

Dugam, S. S., S. D. Bansod, and S. B. Kakade (2009), Pre-monsoon zonal wind Index over Tibetan Plateau and sub-seasonal Indian summer monsoon rainfall variability, Geophysical Research Letters, 36, L11809.

Fan, G. Z., S. W. Luo, and S. H. Lv (1997), The preliminary numerical experiments of effect of anomalous snow cover over Plateau in winter on east and south Asian summer monsoon, Plateau Meteorology (in Chinese), 16(2), 140-152.

Fasullo, J. (2004), A Stratified Diagnosis of the Indian Monsoon-Eurasian Snow Cover Relationship, Journal of Climate, 17(5), 1110-1122.

Furlani, S., and A. Ninfo (2015), Is the present the key to the future?, Earth-Science Reviews, 142, $38-46$.

Gao, J., T. Yao, Valérie Masson-Delmotte, Hans Christian Steen-Larsen, and W. Wang (2019), Collapsing glaciers threaten Asias water supplies, Nature, 565, 19-21.

Gao, Y., F. Chen, D. P. Lettenmaier, J. Xu, L. Xiao, and X. Li (2018), Does elevation-dependent warming hold true above $5000 \mathrm{~m}$ elevation? Lessons from the Tibetan Plateau, npj Climate and Atmospheric Science, 1(1), 19, doi:10.1038/s41612-018-0030-z.

Ge, J., Q. You, and Y. Zhang (2019), Effect of Tibetan Plateau heating on summer extreme precipitation in eastern China, Atmospheric Research, 218, 364-371.

Groisman, P., T. R. Karl, and R. W. Knight (1994a), Observed Impact of Snow Cover on the Heat Balance and the Rise of Continental Spring Temperatures, Nature, 263(5144), 198-200.

Groisman, P., T. R. Karl, R. W. Knight, and G. L. Stenchikov (1994b), Changes of Snow Cover, 
Temperature, and Radiative Heat Balance over the Northern Hemisphere, Journal of Climate, 7(11), 1633-1656.

Halder, S., and P. A. Dirmeyer (2016), Relation of Eurasian Snow Cover and Indian Summer Monsoon Rainfall: Importance of the Delayed Hydrological Effect, Journal of Climate, 30(4), 12731289, doi:10.1175/JCLI-D-16-0033.1.

Hertig, E., C. Beck, H. Wanner, and J. Jacobeit (2015), A review of non-stationarities in climate variability of the last century with focus on the North Atlantic-European sector, Earth-Science Reviews, 147, 1-17.

Huang, X., J. Deng, X. Ma, Y. Wang, Q. Feng, X. Hao, and T. Liang (2016), Spatiotemporal dynamics of snow cover based on multi-source remote sensing data in China, The Cryosphere, 10(5), 2453-2463, doi:10.5194/tc-10-2453-2016.

Huang, X., J. Deng, W. Wang, Q. Feng, and T. Liang (2017), Impact of climate and elevation on snow cover using integrated remote sensing snow products in Tibetan Plateau, Remote Sensing of Environment, 190, 274-288.

Huning, L. S., and A. AghaKouchak (2018), Mountain snowpack response to different levels of warming, Proceedings of the National Academy of Sciences, 115(43), 10932, doi:10.1073/pnas.1805953115.

Immerzeel, W. W., and M. F. P. Bierkens (2012), Asias water balance, Nature Geoscience, 5(12), 841-842, doi:10.1038/ngeo1643.

IPCC (2013), Summary for Policymakers of Climate change 2013: The Physical Science Basis. Contribution of Working Group I to the Fifth Assessment Report of the Intergovernmental Panel on Climate Change Cambridge, UK: Cambridge University Press.

Ji, Z. (2016), Modeling black carbon and its potential radiative effects over the Tibetan Plateau, Advances in Climate Change Research, 7(3), 139-144.

Ji, Z., and S. Kang (2013), Projection of snow cover changes over China under RCP scenarios, Climate Dynamics, 41(3), 589-600, doi:10.1007/s00382-012-1473-2.

Ji, Z., S. Kang, Z. Cong, Q. Zhang, and T. Yao (2015), Simulation of carbonaceous aerosols over the Third Pole and adjacent regions: distribution, transportation, deposition, and climatic effects, Climate Dynamics, 45(9), 2831-2846.

Ji, Z., S. Kang, Q. Zhang, Z. Cong, P. Chen, and M. Sillanpää (2016), Investigation of mineral 
aerosols radiative effects over High Mountain Asia in 1990-2009 using a regional climate model, Atmospheric Research, 178-179, 484-496.

Jin, R., Z. Wu, and P. Zhang (2018), Tibetan Plateau capacitor effect during the summer preceding ENSO: from the Yellow River climate perspective, Climate Dynamics, 51(1), 57-71, doi:10.1007/s00382-017-3906-4.

Kang, S., et al. (2019), Linking atmospheric pollution to cryospheric change in the Third Pole region: current progress and future prospects, National Science Review, 6, 796-809.

Kang, S. C., Y. W. Xu, Q. L. You, W. A. Flugel, N. Pepin, and T. D. Yao (2010), Review of climate and cryospheric change in the Tibetan Plateau, Environmental Research Letters, 5(1), 015101, doi:10.1088/1748-9326/5/1/015101.

Kong, Y., and C.-H. Wang (2017), Responses and changes in the permafrost and snow water equivalent in the Northern Hemisphere under a scenario of $1.5^{\circ} \mathrm{C}$ warming, Advances in Climate Change Research, 8(4), 235-244.

Kraaijenbrink, P. D. A., M. F. P. Bierkens, A. F. Lutz, and W. W. Immerzeel (2017), Impact of a global temperature rise of 1.5 degrees Celsius on Asia's glaciers, Nature, 549(7671), 257-260.

Kripalani, R. H., A. Kulkarni, and S. S. Sabade (2003), Western Himalayan snow cover and Indian monsoon rainfall: A re-examination with INSAT and NCEP/NCAR data, Theoretical and Applied Climatology, 74(1), 1-18, doi:10.1007/s00704-002-0699-z.

Li, C., F. Su, D. Yang, K. Tong, F. Meng, and B. Kan (2018a), Spatiotemporal variation of snow cover over the Tibetan Plateau based on MODIS snow product, 2001-2014, International Journal of Climatology, 38(2), 708-728, doi:10.1002/joc.5204.

Li, D., and C. Wang (2011), Research progress of snow cover and its influence on China climate, Transactions of Atmospheric Sciences (in Chinese), 34(5), 627-636.

Li, P. J. (1996), Response of Tibetan snow cover to global warming, Acta Geograph Sinica (in Chinese), 51(3), 260-265.

Li, W., W. Guo, B. Qiu, Y. Xue, P.-C. Hsu, and J. Wei (2018b), Influence of Tibetan Plateau snow cover on East Asian atmospheric circulation at medium-range time scales, Nature Communications, 9(1), 4243, doi:10.1038/s41467-018-06762-5.

Li, X., G. D. Cheng, H. J. Jin, E. Kang, T. Che, R. Jin, L. Z. Wu, Z. T. Nan, J. Wang, and Y. P. Shen (2008), Cryospheric change in China, Global and Planetary Change, 62(3-4), 210-218, 
doi:10.1016/j.gloplacha.2008.02.001.

Li, Y., H. Tao, B. Su, Z. W. Kundzewicz, and T. Jiang (2019a), Impacts of $1.5^{\circ} \mathrm{C}$ and $2{ }^{\circ} \mathrm{C}$ global warming on winter snow depth in Central Asia, Science of The Total Environment, 651, 2866-2873. Li, Z., F. Qi, L. Zongjie, Y. Ruifeng, G. Juan, and L. Yuemin (2019b), Climate background, fact and hydrological effect of multiphase water transformation in cold regions of the Western China: A review, Earth-Science Reviews, 190, 33-57.

Lin, H., and Z. Wu (2011), Contribution of the Autumn Tibetan Plateau Snow Cover to Seasonal Prediction of North American Winter Temperature, Journal of Climate, 24(11), 2801-2813, doi:10.1175/2010JCLI3889.1.

Lin, H., and Z. Wu (2012), Contribution of Tibetan Plateau Snow Cover to the Extreme Winter Conditions of 2009/10, Atmosphere-Ocean, 50(1), 86-94, doi:10.1080/07055900.2011.649036.

Liu, G., R. Wu, Y. Zhang, and S. Nan (2014a), The summer snow cover anomaly over the Tibetan Plateau and its association with simultaneous precipitation over the mei-yu-baiu region, Advances in Atmospheric Sciences, 31(4), 755-764, doi:10.1007/s00376-013-3183-z.

Liu, G., R. G. Wu, and Y. Z. Zhang (2014b), Persistence of Snow Cover Anomalies over the Tibetan Plateau and the Implications for Forecasting Summer Precipitation over the Meiyu-Baiu Region, Atmospheric and Oceanic Science Letters, 7(2), 115-119, doi:10.3878/j.issn.1674-2834.13.0074.

Liu, X., and B. Chen (2000), Climatic warming in the Tibetan Plateau during recent decades, International Journal of Climatology, 20(14), 1729-1742.

Lü, J.-M., J.-H. Ju, S.-J. Kim, J.-Z. Ren, and Y.-X. Zhu (2008), Arctic Oscillation and the autumn/winter snow depth over the Tibetan Plateau, Journal of Geophysical Research: Atmospheres, 113(D14), D14117.

Luo, Y. (1995), Studies on the effect of snow cover over the Qinghai-Xizang Plateau in winter and spring on general circulation over east Asia in summer Plateau Meteorology (in Chinese), 14(4), $505-512$.

Lyu, M., M. Wen, and Z. Wu (2018), Possible contribution of the inter-annual Tibetan Plateau snow cover variation to the Madden-Julian oscillation convection variability, International Journal of Climatology, 38(10), 3787-3800, doi:10.1002/joc.5533.

Mao, J. (2010), Interannual Variability of Snow Depth over the Tibetan Plateau and Its Associated Atmospheric Circulation Anomalies, Atmospheric and Oceanic Science Letters, 3(4), 213-218. 
911 from reanalysis to regional climate simulations, Hydrol. Earth Syst. Sci., 17(10), 3921-3936, 912 doi:10.5194/hess-17-3921-2013.

913 Mölg, T., F. Maussion, and D. Scherer (2014), Mid-latitude westerlies as a driver of glacier 914 variability in monsoonal High Asia, Nature climate change, 4, 68-73.

915 Morán-Tejeda, E., J. I. López-Moreno, and M. Beniston (2013), The changing roles of temperature 916 and precipitation on snowpack variability in Switzerland as a function of altitude, Geophysical 917 Research Letters, 40(10), 2131-2136, doi:10.1002/grl.50463.

918 Pepin, N. C., and Coauthors (2015), Elevation-dependent warming in mountain regions of the world, $919 \quad$ Nature climate change, 5, 424-430.

920 Pepin, N. C., H. Deng, H. Zhang, F. Zhang, S. Kang, and T. Yao (2019), An examination of 921 temperature trends at high elevations across the Tibetan Plateau: The use of MODIS LST to 922 understand patterns of elevation-dependent warming, Journal of Geophysical Research: 923 Atmospheres, O(ja), doi:10.1029/2018JD029798.

$924 \mathrm{Pu}, \mathrm{Z} . \mathrm{X}$., and L. Xu (2009), MODIS/Terra observed snow cover over the Tibet Plateau: distribution, variation and possible connection with the East Asian Summer Monsoon (EASM), Theoretical and Applied Climatology, 97(3-4), 265-278, doi:10.1007/s00704-008-0074-9. cover over the Tibetan Plateau, Geophysical Research Letters, 34(6), L06706.

Qian, Y., M. G. Flanner, L. R. Leung, and W. Wang (2011), Sensitivity studies on the impacts of 930 Tibetan Plateau snowpack pollution on the Asian hydrological cycle and monsoon climate, Atmos. 931 Chem. Phys., 11(5), 1929-1948, doi:10.5194/acp-11-1929-2011. Qian, Y. F., Y. Q. Zheng, Y. Zhang, and M. Q. Miao (2003), Responses of Chinas summer monsoon climate to snow anomaly over the Tibetan Plateau, International Journal of Climatology, 23(6), 593-613, doi:10.1002/joc.901.

Qin, D. H., S. Y. Liu, and P. J. Li (2006), Snow cover distribution, variability, and response to climate change in western China, Journal of Climate, 19(9), 1820-1833.

937 Qin, D. H., J. Yang, J. Ren, S. Kang, C. Xiao, Y. Ding, and S. Zhang (2018), Cryospheric Science: 938 research framework and disciplinary system, National Science Review, 5(2), 255-268, 939 doi:10.1093/nsr/nwx108. 
Qin, D. H., B. Zhou, and C. Xiao (2014), Progress in studies of cryospheric changes and their impacts on climate of China, Journal of Meteorological Research, 28(5), 732-746, doi:10.1007/s13351-014-4029-z.

Qiu, J. (2008), The third pole, Nature, 454(7203), 393-396.

Qiu, J. (2013), Monsoon Melee, Science, 340(6139), 1400-1401.

Qiu, J. (2016), Trouble in tibet, Nature, 529(7585), 142.

Qu, B., J. Ming, S. C. Kang, G. S. Zhang, Y. W. Li, C. D. Li, S. Y. Zhao, Z. M. Ji, and J. J. Cao (2014), The decreasing albedo of the Zhadang glacier on western Nyainqentanglha and the role of light-absorbing impurities, Atmos. Chem. Phys., 14(20), 11117-11128.

Qu, X., and A. Hall (2006), Assessing Snow Albedo Feedback in Simulated Climate Change, Journal of Climate, 19(11), 2617-2630, doi:10.1175/JCLI3750.1.

Räisänen, J. (2008), Warmer climate: less or more snow?, Climate Dynamics, 30(2), 307-319, doi:10.1007/s00382-007-0289-y.

Ramanathan, V., M. V. Ramana, G. Roberts, D. Kim, C. Corrigan, C. Chung, and D. Winker (2007), Warming trends in Asia amplified by brown cloud solar absorption, Nature, 448(7153), 575-578, doi:10.1038/nature06019.

Rangwala, I., J. Miller, G. Russell, and M. Xu (2010a), Using a global climate model to evaluate the influences of water vapor, snow cover and atmospheric aerosol on warming in the Tibetan Plateau during the twenty-first century, Climate Dynamics, 34(6), 859-872.

Rangwala, I., J. R. Miller, G. L. Russell, and M. Xu (2010b), Using a global climate model to evaluate the influences of water vapor, snow cover and atmospheric aerosol on warming in the Tibetan Plateau during the twenty-first century, Climate Dynamics, 34(6), 859-872, doi:10.1007/s00382-009-0564-1.

Ren, Y., Y. Lü, A. Comber, B. Fu, P. Harris, and L. Wu (2019), Spatially explicit simulation of land use/land cover changes: Current coverage and future prospects, Earth-Science Reviews, 190, 398415.

Robertson, A. W., A. Kumar, M. Peña, and F. Vitart (2015), Improving and Promoting Subseasonal to Seasonal Prediction, Bulletin of the American Meteorological Society, 96(3), ES49-ES53, doi:10.1175/BAMS-D-14-00139.1.

Robock, A., M. Mu, K. Vinnikov, and D. Robinson (2003), Land surface conditions over Eurasia 
and Indian summer monsoon rainfall, Journal of Geophysical Research: Atmospheres, 108(D4), 4131.

Russo, S., J. Sillmann, S. Sippel, M. J. Barcikowska, C. Ghisetti, M. Smid, and B. O’Neill (2019), Half a degree and rapid socioeconomic development matter for heatwave risk, Nature Communications, 10(1), 136, doi:10.1038/s41467-018-08070-4.

Schiemann, R., D. Lüthi, and C. Schär (2009), Seasonality and Interannual Variability of the Westerly Jet in the Tibetan Plateau Region, Journal of Climate, 22(11), 2940-2957, doi:10.1175/2008JCLI2625.1.

Senan, R., Y. J. Orsolini, A. Weisheimer, F. Vitart, G. Balsamo, T. N. Stockdale, E. Dutra, F. J. Doblas-Reyes, and D. Basang (2016), Impact of springtime Himalayan-Tibetan Plateau snowpack on the onset of the Indian summer monsoon in coupled seasonal forecasts, Climate Dynamics, 47(9), $2709-2725$.

Seneviratne, S. I., T. Corti, E. L. Davin, M. Hirschi, E. B. Jaeger, I. Lehner, B. Orlowsky, and A. J. Teuling (2010), Investigating soil moisture-climate interactions in a changing climate: A review, Earth-Science Reviews, 99(3), 125-161.

Shaman, J., and E. Tziperman (2005), The effect of ENSO on Tibetan plateau snow depth: A stationary wave teleconnection mechanism and implications for the south Asian monsoons, Journal of Climate, 18(12), 2067-2079.

Shaman, J., and E. Tziperman (2007), Summertime ENSO-North African-Asian jet teleconnection and implications for the Indian monsoons, Geophysical Research Letters, 34(11), L11702.

Shen, S. S. P., R. Yao, J. Ngo, A. M. Basist, N. Thomas, and T. Yao (2015), Characteristics of the Tibetan Plateau snow cover variations based on daily data during 1997-2011, Theoretical and Applied Climatology, 120(3), 445-453, doi:10.1007/s00704-014-1185-0.

Shi, Y., X. Gao, J. Wu, and F. Giorgi (2011), Changes in snow cover over China in the 21st century as simulated by a high resolution regional climate model, Environmental Research Letters, 6(4), 045401, doi:10.1088/1748-9326/6/4/045401.

Smith, T., and B. Bookhagen (2018), Changes in seasonal snow water equivalent distribution in High Mountain Asia (1987 to 2009), Science Advances, 4(1), e1701550, doi:10.1126/sciadv.1701550.

Sun, J., et al. (2018), Linkages of the dynamics of glaciers and lakes with the climate elements over 
the Tibetan Plateau, Earth-Science Reviews, 185, 308-324.

Tan, X., W. Zhenni, M. Xingmin, G. Peng, Z. Guangju, S. Wenyi, and G. Chaojun (2019), Spatiotemporal changes in snow cover over China during 1960-2013, Atmospheric Research, 218, $183-194$.

Tang, Z., J. Wang, H. Li, and L. Yan (2013), Spatiotemporal changes of snow cover over the Tibetan plateau based on cloud-removed moderate resolution imaging spectroradiometer fractional snow cover product from 2001 to 2011, Journal of Applied Remote Sensing, 7, 073582.

Tao, S.-y., and Y.-h. Ding (1981), Observational Evidence of the Influence of the Qinghai-Xizang (Tibet) Plateau on the Occurrence of Heavy Rain and Severe Convective Storms in China, Bulletin of the American Meteorological Society, 62(1), 23-30.

UNFCCC (2015), Adoption of the Paris Agreement. FCCC/CP/2015/10/Add.1, pp. 1-32, Paris. Vitart, F., A. Robertson, and D. L. T. Anderson (2012), Subseasonal to Seasonal Prediction Project: Bridging the gap between weather and climate, WMO Bulletin, 61(2), 23.

Vuille, M., et al. (2018), Rapid decline of snow and ice in the tropical Andes - Impacts, uncertainties and challenges ahead, Earth-Science Reviews, 176, 195-213.

Vuille, M., B. Francou, P. Wagnon, I. Juen, G. Kaser, B. G. Mark, and R. S. Bradley (2008), Climate change and tropical Andean glaciers: Past, present and future, Earth-Science Reviews, 89(3), 79-96. Walker, G. R. (1990), Correlations in seasonal variations of weather, Memo. Indian Meteorol. Dep., $21,22-45$

Wang, A., L. Xu, and X. Kong (2018a), Assessments of the Northern Hemisphere snow cover response to 1.5 and $2.0^{\circ} \mathrm{C}$ warming, Earth Syst. Dynam., 9(2), 865-877, doi:10.5194/esd-9-8652018.

Wang, C., K. Yang, Y. Li, D. Wu, and Y. Bo (2017a), Impacts of Spatiotemporal Anomalies of Tibetan Plateau Snow Cover on Summer Precipitation in East China, Journal of Climate, 30, 885903, doi:10.1175/JCLI-D-16-0041.1.

Wang, S. (2017), Progresses in variability of snow cover over the Qinghai-Tibetan Plateau and its impact on water resources in China, Plateau Meteorology (in Chinese), 36(5), 1153-1164.

Wang, T., S. Peng, X. Lin, and J. Chang (2013), Declining snow cover may affect spring phenological trend on the Tibetan Plateau, Proceedings of the National Academy of Sciences, 110(31), E2854, doi:10.1073/pnas.1306157110. 
Wang, W., X. Huang, J. Deng, H. Xie, and T. Liang (2015), Spatio-Temporal Change of Snow Cover and Its Response to Climate over the Tibetan Plateau Based on an Improved Daily Cloud-Free Snow Cover Product, Remote Sensing, 7(1), 169-194.

Wang, X., C. Wu, H. Wang, A. Gonsamo, and Z. Liu (2017b), No evidence of widespread decline of snow cover on the Tibetan Plateau over 2000-2015, Scientific Reports, 7(1), 14645, doi:10.1038/s41598-017-15208-9.

Wang, Y., and X. Xu (2018), Impact of ENSO on the Thermal Condition over the Tibetan Plateau, Journal of the Meteorological Society of Japan, 96(3), 269-281, doi:10.2151/jmsj.2018-032.

Wang, Z., R. Wu, S. Chen, G. Huang, G. Liu, and L. Zhu (2018b), Influence of Western Tibetan Plateau Summer Snow Cover on East Asian Summer Rainfall, Journal of Geophysical Research: Atmospheres, 123(5), 2371-2386.

Wang, Z., R. Wu, and G. Huang (2017c), Low-frequency snow changes over the Tibetan Plateau, International Journal of Climatology, 38(2), 949-963, doi:10.1002/joc.5221.

Wang, Z., R. Wu, P. Zhao, S.-L. Yao, and X. Jia (2019), Formation of Snow Cover Anomalies Over the Tibetan Plateau in Cold Seasons, Journal of Geophysical Research: Atmospheres, 124(9), 48734890, doi:10.1029/2018JD029525.

Wei, Z. G., and W. J. Dong (2015), Assessment of simulations of snow depth in the Qinghai-Tibetan Plateau using CMIP5 multi-models, Arctic Antarctic and Alpine Research, 47(4), 611-625.

Wu, J., and Z. Wu (2019), Inter-decadal change of the spring North Atlantic Oscillation impact on the summer Pamir-Tienshan snow cover, International Journal of Climatology, 39(2), 629-642, doi:10.1002/joc.5831.

Wu, R., and B. P. Kirtman (2007), Observed Relationship of Spring and Summer East Asian Rainfall with Winter and Spring Eurasian Snow, Journal of Climate, 20(7), 1285-1304.

Wu, R., Z. Wen, S. Yang, and Y. Li (2010), An Interdecadal Change in Southern China Summer Rainfall around 1992/93, Journal of Climate, 23(9), 2389-2403, doi:10.1175/2009JCLI3336.1.

Wu, T. W., and Z. A. Qian (2003), The relation between the Tibetan winter snow and the Asian summer monsoon and rainfall: An observational investigation, Journal of Climate, 16(12), 20382051.

Wu, Z. W., Z. Jiang, J. Li, S. Zhong, and L. Wang (2012), Possible association of the western Tibetan Plateau snow cover with the decadal to interdecadal variations of northern China heatwave 
frequency, Climate Dynamics, 39(9-10), 2393-2402, doi:10.1007/s00382-012-1439-4.

Wu, Z. W., J. Li, Z. Jiang, and T. Ma (2011), Modulation of the Tibetan Plateau Snow Cover on the ENSO Teleconnections: From the East Asian Summer Monsoon Perspective, Journal of Climate, 25(7), 2481-2489, doi:10.1175/JCLI-D-11-00135.1.

Wu, Z. W., P. Zhang, H. Chen, and Y. Li (2016), Can the Tibetan Plateau snow cover influence the interannual variations of Eurasian heat wave frequency?, Climate Dynamics, 46(11-12), 3405-3417. Xiao, C. D., et al. (2007), Observed changes of cryosphere in China over the second half of the 20th century: an overview, Annals of Glaciology, 46, 382-390.

Xiao, C. D., D. H. Qin, T. D. Yao, Y. J. Ding, S. Y. Liu, L. Zhao, and Y. J. Liu (2008), Progress on observation of cryospheric components and climate-related studies in China, Advances in Atmospheric Sciences, 25(2), 164-180.

Xiao, Z., and A. Duan (2016), Impacts of Tibetan Plateau Snow Cover on the Interannual Variability of the East Asian Summer Monsoon, Journal of Climate, 29(23), 8495-8514, doi:10.1175/JCLI-D16-0029.1.

Xie, L., T. Yan, L. J. Pietrafesa, T. Karl, and X. Xu (2005), Relationship between western North Pacific typhoon activity and Tibetan Plateau winter and spring snow cover, Geophysical Research Letters, 32(16), L16703.

Xin, X., T. Zhou, and R. Yu (2010), Increased Tibetan Plateau snow depth: An indicator of the connection between enhanced winter NAO and late-spring tropospheric cooling over East Asia, Advances in Atmospheric Sciences, 27(4), 788-794, doi:10.1007/s00376-009-9071-x.

Xu, L., and P. Dirmeyer (2012), Snow-Atmosphere Coupling Strength. Part II: Albedo Effect Versus Hydrological Effect, Journal of Hydrometeorology, 14(2), 404-418.

Xu, W., L. Ma, M. Ma, H. Zhang, and W. Yuan (2017), Spatial-Temporal Variability of Snow Cover and Depth in the Qinghai-Tibetan Plateau, Journal of Climate, 30(4), 1521-1533. Xu, X., and Y. Wang (2016), Analysis of the influence of ENSO on snow depth over Qinghai-Xizang Plateau and its continuity, Plateau Meteorology (in Chinese), 35(1), 1-12.

Yang, J., L. Jiang, C. B. Ménard, K. Luojus, J. Lemmetyinen, and J. Pulliainen (2015), Evaluation of snow products over the Tibetan Plateau, Hydrological Processes, 29(15), 3247-3260.

Yang, K., B. S. Ye, D. G. Zhou, B. Y. Wu, T. Foken, J. Qin, and Z. Y. Zhou (2011), Response of hydrological cycle to recent climate changes in the Tibetan Plateau, Climatic Change, 109(3-4), 
517-534, doi:10.1007/s10584-011-0099-4.

Yang, M., F. E. Nelson, N. I. Shiklomanov, D. Guo, and G. Wan (2010), Permafrost degradation and its environmental effects on the Tibetan Plateau: A review of recent research, Earth-Science Reviews, 103(1), 31-44.

Yang, M., X. Wang, G. Pang, G. Wan, and Z. Liu (2019), The Tibetan Plateau cryosphere: Observations and model simulations for current status and recent changes, Earth-Science Reviews, 190, 353-369.

Yao, T., et al. (2012), Different glacier status with atmospheric circulations in Tibetan Plateau and surroundings, Nature Climate Change, 2(9), 663-667, doi:10.1038/nclimate1580.

Yao, T., F. Wu, L. Ding, J. Sun, L. Zhu, S. Piao, T. Deng, X. Ni, H. Zheng, and H. Ouyang (2015), Multispherical interactions and their effects on the Tibetan Plateaus earth system: a review of the recent researches, National Science Review, 2(4), 468-488, doi:10.1093/nsr/nwv070.

Yao, T., et al. (2019), Recent Third Pole's rapid warming accompanies cryospheric melt and water cycle intensification and interactions between monsoon and environment: multi-disciplinary approach with observation, modeling and analysis, Bulletin of the American Meteorological Society, 100(3), 423-444, doi:10.1175/BAMS-D-17-0057.1.

Yao, T. D., Y. Q. Wang, S. Y. Liu, J. C. Pu, Y. P. Shen, and A. X. Lu (2004), Recent glacial retreat in High Asia in China and its impact on water resource in Northwest China, Science in China Series D-Earth Sciences, 47(12), 1065-1075.

Yasunari, T. (2007), Role of Land-Atmosphere Interaction on Asian Monsoon Climate, Journal of the Meteorological Society of Japan, 85B, 55-75.

Yasunari, T., A. Kitoh, and T. Tokioka (1991), Local and Remote Responses to Excessive Snow Mass over Eurasia Appearing in the Northern Spring and Summer Climate-A Study with the MRI GCM, Journal of the Meteorological Society of Japan, 69(4), 473-487.

Ye, K., and R. Wu (2017), Autumn snow cover variability over northern Eurasia and roles of atmospheric circulation, Advances in Atmospheric Sciences, 34(7), 847-858.

Ye, K., R. Wu, and Y. Liu (2015), Interdecadal change of Eurasian snow, surface temperature, and atmospheric circulation in the late 1980s, Journal of Geophysical Research: Atmospheres, 120(7), $2738-2753$

Yeo, S.-R., W. Kim, and K.-Y. Kim (2017), Eurasian snow cover variability in relation to warming 
trend and Arctic Oscillation, Climate Dynamics, 48(1), 499-511, doi:10.1007/s00382-016-3089-4. You, Q. L., Z. H. Jiang, G. Moore, Y. T. Bao, L. Kong, and S. C. Kang (2017), Revisiting the relationship between observed warming and surface pressure in the Tibetan Plateau, Journal of Climate, 30, 1721-1737.

You, Q. L., S. C. Kang, G. Y. Ren, K. Fraedrich, N. Pepin, Y. P. Yan, and L. J. Ma (2011), Observed changes in snow depth and number of snow days in the eastern and central Tibetan Plateau, Climate Research, 46, 171-183.

You, Q. L., J. Min, and S. Kang (2016), Rapid warming in the Tibetan Plateau from observations and CMIP5 models in recent decades, International Journal of Climatology, 36(6), 2660-2670, doi:10.1002/joc.4520.

You, Q. L., J. Min, W. Zhang, N. Pepin, and S. Kang (2015), Comparison of multiple datasets with gridded precipitation observations over the Tibetan Plateau, Climate Dynamics, 45(3), 791-806, doi:10.1007/s00382-014-2310-6.

You, Q. L., Y. Q. Zhang, X. Xie, and F. Wu (2019), Robust elevation dependency warming over the Tibetan Plateau under global warming of $1.5^{\circ} \mathrm{C}$ and $2{ }^{\circ} \mathrm{C}$, Climate Dynamics, in press, doi:10.1007/s00382-019-04775-4.

Yu, R., and T. Zhou (2004), Impacts of winter-NAO on March cooling trends over subtropical Eurasia continent in the recent half century, Geophysical Research Letters, 31(12), L12204, doi:10.1029/2004GL019814.

Yuan, C. X., T. Tozuka, T. Miyasaka, and T. Yamagata (2009), Respective influences of IOD and ENSO on the Tibetan snow cover in early winter, Climate Dynamics, 33(4), 509-520, doi:10.1007/s00382-008-0495-2.

Yuan, C. X., T. Tozuka, and T. Yamagata (2012), IOD influence on the early winter tibetan plateau snow cover: diagnostic analyses and an AGCM simulation, Climate Dynamics, 39(7), 1643-1660, doi:10.1007/s00382-011-1204-0.

Zhang, G., H. Xie, T. Yao, T. Liang, and S. Kang (2012), Snow cover dynamics of four lake basins over Tibetan Plateau using time series MODIS data (2001-2010), Water Resources Research, 48(10), doi:10.1029/2012WR011971.

Zhang, R., R. Zhang, and Z. Zuo (2016), An overview of wintertime snow cover characteristics over China and the impact of Eurasian snow cover on Chinese climate, Journal of Applied 
Meteorological Science (in Chinese), 27(5), 513-526.

Zhang, R. N., R. Zhang, and Z. Zuo (2017), Impact of Eurasian Spring Snow Decrement on East Asian Summer Precipitation, Journal of Climate, 30(9), 3421-3437, doi:10.1175/JCLI-D-16-0214.1 Zhang, S., and S. Tao (2001), Influences of Snow Cover over the Tibetan Plateau on Asian Summer Monsoon, Chinese Journal of Atmospheric Sciences (in Chinese), 25(3), 372-390.

Zhang, T. (2005), Influence of the seasonal snow cover on the ground thermal regime: An overview, Reviews of Geophysics, 43(4), RG4002, doi:10.1029/2004RG000157.

Zhang, T. T., J. P. Yan, G. M. Liao, and H. An (2014), Spatiotemporal distribution of snow disaster on Tibetan Plateau in recent 51 years, Bulletin of soil and water conservation (in Chinese), 34(1), $242-251$

Zhang, Y., et al. (2018), Black carbon and mineral dust in snow cover on the Tibetan Plateau, The Cryosphere, 12(2), 413-431, doi:10.5194/tc-12-413-2018.

Zhang, Y. S., T. Li, and B. Wang (2004), Decadal change of the spring snow depth over the Tibetan Plateau: The associated circulation and influence on the East Asian summer monsoon, Journal of Climate, 17(14), 2780-2793.

Zhang, Y. S., and N. Ma (2018), Spatiotemporal variability of snow cover and snow water equivalent in the last three decades over Eurasia, Journal of Hydrology, 559, 238-251.

Zhao, H., and G. W. K. Moore (2002), On the relationship between Dasuopu Snow Accumulation and the Asian Summer Monsoon, Geophysical Research Letters, 29(24), 2222, doi:10.1029/2002GL015757.

Zhao, H., and G. W. K. Moore (2004), On the relationship between Tibetan snow cover, the Tibetan plateau monsoon and the Indian summer monsoon, Geophysical Research Letters, 31(14), L14204, doi:10.1029/2004GL020040.

Zhao, H., and G. W. K. Moore (2006), Reduction in Himalayan snow accumulation and weakening of the trade winds over the Pacific since the 1840s, Geophysical Research Letters, 33(17), L17709. Zhong, X., T. Zhang, S. Kang, K. Wang, L. Zheng, Y. Hu, and H. Wang (2018), Spatiotemporal variability of snow depth across the Eurasian continent from 1966 to 2012, The Cryosphere, 12(1), 227-245, doi:10.5194/tc-12-227-2018.

Zhou, B., Z. Wang, Y. Shi, Y. Xu, and Z. Han (2018), Historical and Future Changes of Snowfall Events in China under a Warming Background, Journal of Climate, 31(15), 5873-5889, 

doi:10.1175/JCLI-D-17-0428.1.

1181 Zhu, X., and W. J. Dong (2013), Evaluation and projection of northern hemisphere March-April 1182 snow covered area simulated by CMIP5 coupled climate models, Advances in Climate Change 1183 Research (in Chinese), 9(3), 173-234.

1184 Zhu, Y., and Y. Ding (2007), Influences of Snow Cover over Tibetan Plateau on Weather and Climate: 1185 Advances and Problems, Meteorological Science and Technology (in Chinese), 35(1), 1-8.

1186 Zhu, Y., H. Liu, Y. Ding, F. Zhang, and W. Li (2015), Interdecadal variation of spring snow depth 1187 over the Tibetan Plateau and its influence on summer rainfall over East China in the recent 30 years, 1188 International Journal of Climatology, 35(12), 3654-3660.

1189 Zhu, Z., and C. E. Woodcock (2014), Automated cloud, cloud shadow, and snow detection in 1190 multitemporal Landsat data: An algorithm designed specifically for monitoring land cover change, 1191 Remote Sensing of Environment, 152, 217-234.

1192 Zuo, Z., Y. Song, W. Wanqiu, K. Arun, X. Yan, and Z. Renhe (2011), Relationship between 1193 anomalies of Eurasian snow and southern China rainfall in winter, Environmental Research Letters, 1194 6(4), 045402.

1195 Zuo, Z., R. Zhang, B. Wu, and X. Rong (2012), Decadal variability in springtime snow over Eurasia: 1196 Relation with circulation and possible influence on springtime rainfall over China, International Journal of Climatology, 32(9), 1336-1345, doi:10.1002/joc.2355. 
1210 Table 1. Summary of changes of snow cover over the Tibetan Plateau and its adjacent

1211 territories in recent decades.

\begin{tabular}{|c|c|c|c|c|}
\hline Study region & Dataset & Study period & Results & Reference \\
\hline China & $\begin{array}{l}\text { Snow cover from } \\
201 \\
\text { meteorological } \\
\text { stations }\end{array}$ & $1960-2013$ & $\begin{array}{l}\text { Increasing trends of mean annual } \\
\text { daily snow depth and the number } \\
\text { of snow cover days were } \\
\text { statistically insignificant }\end{array}$ & $\begin{array}{l}\text { Tan et al., } \\
\text { 2019] }\end{array}$ \\
\hline Mountain & $\begin{array}{l}\text { Snow } \quad \text { water } \\
\text { equivalent from } \\
\text { passive } \\
\text { microwave data }\end{array}$ & 1987-2009 & $\begin{array}{l}\text { An overall decrease in snow water } \\
\text { equivalent }\end{array}$ & $\begin{array}{l}\text { [Smith and } \\
\text { Bookhagen, } \\
2018]\end{array}$ \\
\hline Tibetan Plateau & $\begin{array}{ll}\text { Snow } & \text { cover } \\
\text { fraction } & \text { from } \\
\text { MODIS } & \end{array}$ & 2001-2014 & $\begin{array}{l}\text { Snow cover has slightly decreased } \\
\text { by about } 1.1 \%\end{array}$ & $\begin{array}{l}{\left[\begin{array}{ll}C & \text { Li }\end{array} \text { et al. }\right.} \\
\text { 2018a }]\end{array}$ \\
\hline Tibetan Plateau & $\begin{array}{ll}\text { Snow } & \text { cover } \\
\text { fraction } & \text { from } \\
\text { MODIS } & \end{array}$ & $2000-2006$ & $\begin{array}{l}\text { Overall accuracy of MODIS } \\
\text { snow data is about } 90 \%\end{array}$ & $\begin{array}{l}{[P u \text { and } X u,} \\
\text { 2009; Pu et al., } \\
\text { 2007] }\end{array}$ \\
\hline $\begin{array}{lr}\text { Eastern } & \text { and } \\
\text { central } & \text { Tibetan } \\
\text { Plateau } & \end{array}$ & $\begin{array}{l}69 \text { stations above } \\
2000 \mathrm{~m} \quad \text { from } \\
\text { Chinese } \\
\text { Meteorological } \\
\text { Administration }\end{array}$ & 1961-2005 & $\begin{array}{l}\text { Long term trends for both snow } \\
\text { depth and snow cover are weakly } \\
\text { positive }\end{array}$ & $\begin{array}{l}\text { YYou et al., } \\
\text { 2011] }\end{array}$ \\
\hline $\begin{array}{l}\text { Eastern Tibetan } \\
\text { Plateau }\end{array}$ & 60 stations & 1958-1992 & $\begin{array}{l}\text { The winter snow cover over the } \\
\text { TP bears a pronounced quasi- } \\
\text { biennial oscillation }\end{array}$ & $\begin{array}{l}\text { [L Chen and Wu, } \\
2000]\end{array}$ \\
\hline Tibetan Plateau & $\begin{array}{l}\text { MODIS daily } \\
\text { snow products and } \\
\text { the Interactive } \\
\text { Multi-sensor } \\
\text { Snow and Ice } \\
\text { Mapping System } \\
\text { (IMS) }\end{array}$ & $2000-2015$ & $\begin{array}{l}\text { No widespread decline of snow } \\
\text { cover }\end{array}$ & $\begin{array}{l}{[X \text { Wang et al., }} \\
2017 \mathrm{~b}]\end{array}$ \\
\hline Tibetan Plateau & $\begin{array}{l}\text { Snow cover and } \\
\text { snow water } \\
\text { equivalent from } \\
\text { the National Snow } \\
\text { and Ice Data } \\
\text { Center } \\
\text { (NSIDC) }\end{array}$ & 1979-2006 & $\begin{array}{l}\text { Remarkable regional differences } \\
\text { in trends. Strong seasonal } \\
\text { differences }\end{array}$ & $\begin{array}{l}{[Z \text { Wang et al., }} \\
2017 \mathrm{c}]\end{array}$ \\
\hline Tibetan Plateau & 50 stations & $1979-2010$ & $\begin{array}{l}\text { Spring snow depth decreased after } \\
2002\end{array}$ & $\begin{array}{l}{\left[\begin{array}{ll}Y & \text { Zhu et al., } \\
2015\end{array}\right]}\end{array}$ \\
\hline
\end{tabular}




\begin{tabular}{|c|c|c|c|c|}
\hline Tibetan Plateau & $\begin{array}{l}\text { Snow } \\
\text { fraction } \\
\text { MODIS }\end{array}$ & $2003-2010$ & Decrease since 2003 & $\begin{array}{l}\text { [W Wang et al., } \\
\text { 2015] }\end{array}$ \\
\hline Tibetan Plateau & $\begin{array}{l}\text { Snow } \\
\text { fraction } \\
\text { MODIS }\end{array}$ & $2003-2014$ & $\begin{array}{l}\text { Overall accuracy in snow cover } \\
\text { over the TP is } 66.7 \%\end{array}$ & [Dai et al., 2017] \\
\hline Tibetan Plateau & $\begin{array}{l}\text { snow cover } \\
\text { fraction data of } \\
\text { the Northern } \\
\text { Hemisphere Snow } \\
\text { Cover Version } 4.1\end{array}$ & $1966-2016$ & $\begin{array}{l}\text { Large interannual variations of } \\
\text { snow cover in cold seasons }\end{array}$ & $\begin{array}{l}\text { [Z Wang et al., } \\
\text { 2019] }\end{array}$ \\
\hline
\end{tabular}

1212

1213

1214

1215

1216

1217

1218

1219

1220

1221

1222

1223

1224

1225

1226

1227

1228

1229

1230 

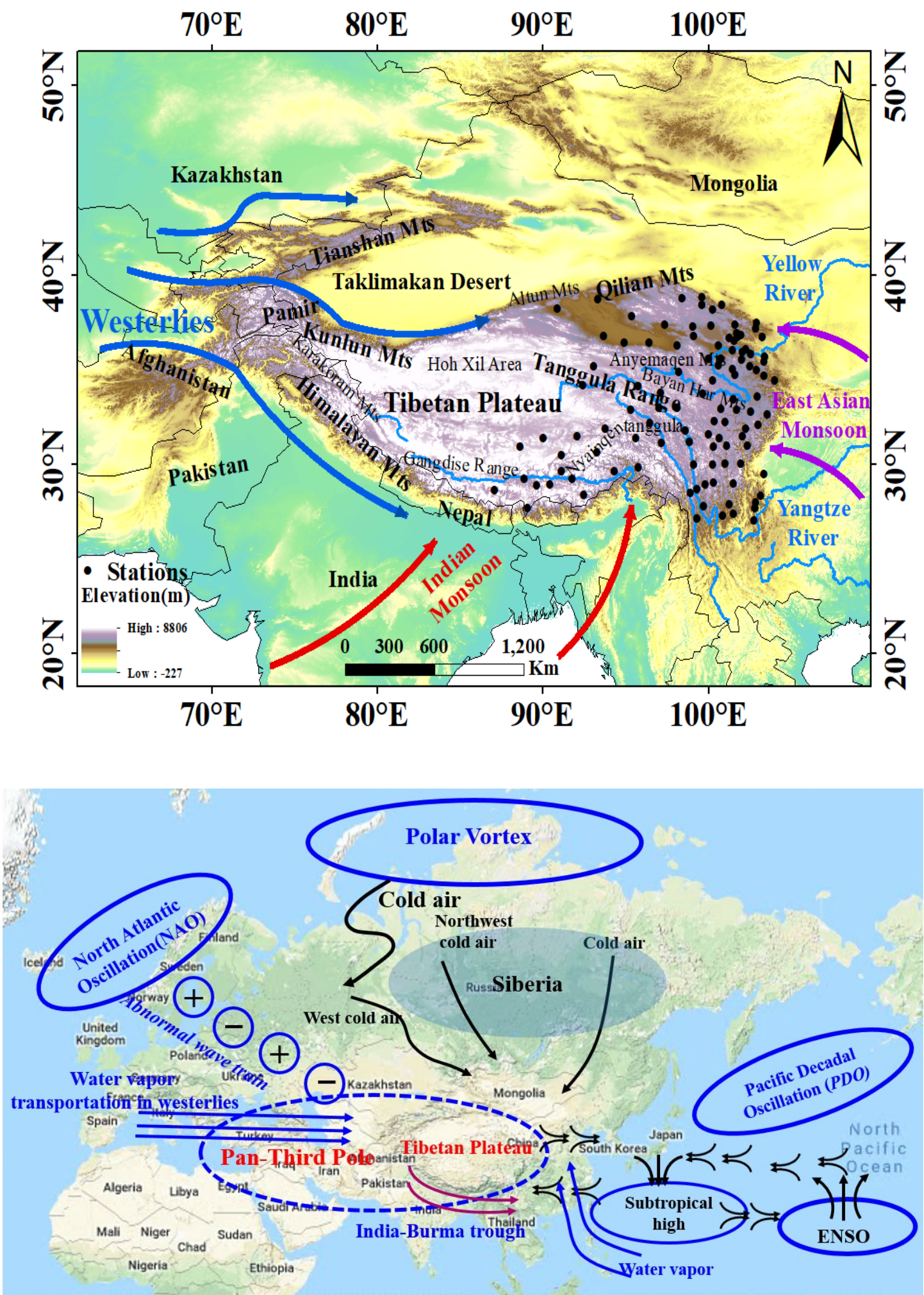

1233 Figure 1. Topographic map (top panel) of the Tibetan Plateau and its adjacent regions,

1234 including the main mountain chains, the 108 observation stations in the regions, and

1235 the dominant atmospheric circulations (the Indian monsoon, East Asian monsoon, and 
1236 Westerlies). The climate patterns and water vapor transportation (bottom panel) around 1237 the Tibetan Plateau and Pan-Third Pole including as ENSO, PDO and NAO.

1238

1239

1240

1241

1242

1243 


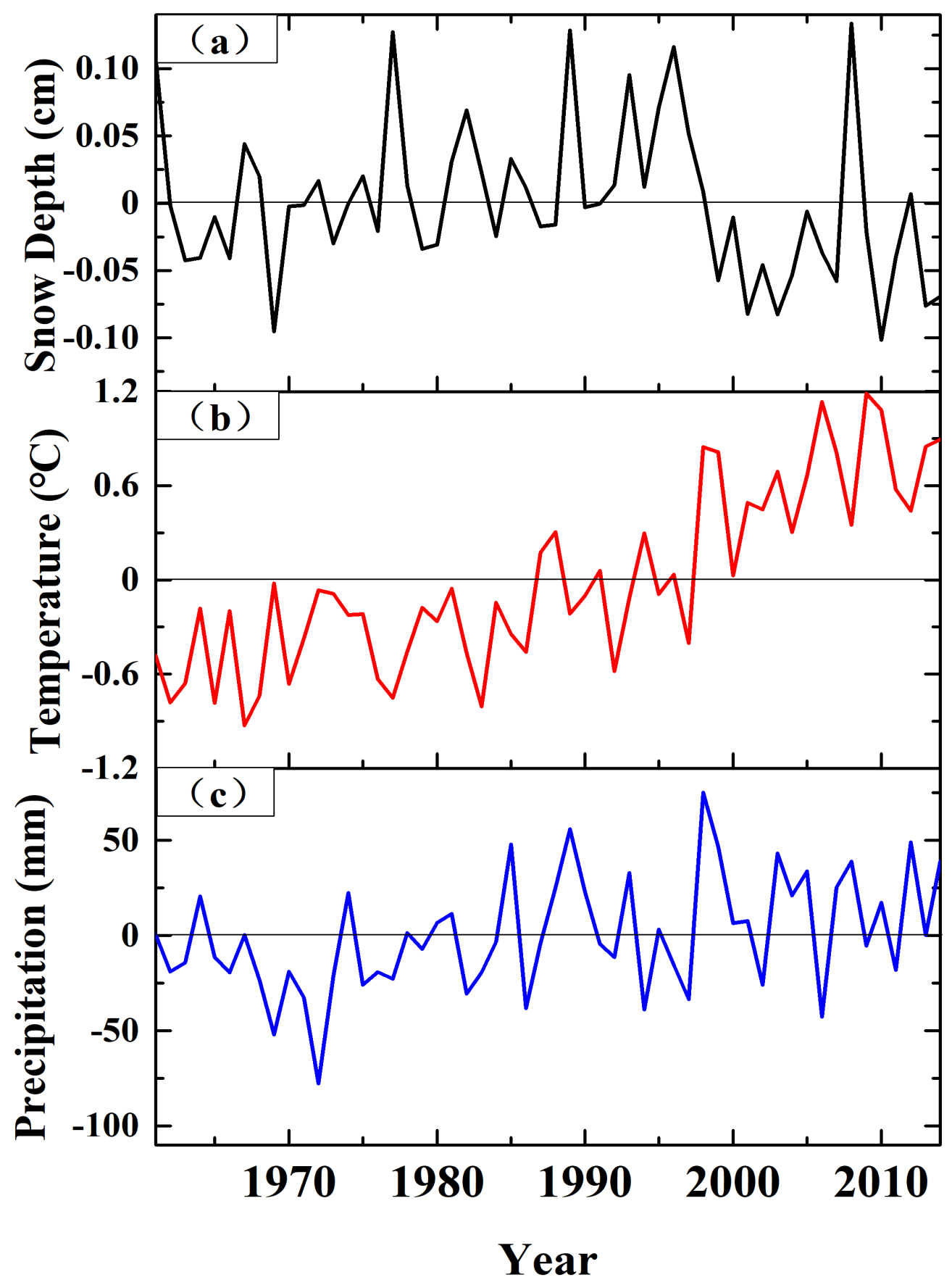

1245 Figure 2. Variation of a) annual mean snow depth, b) temperature and c) precipitation

1246 based on 108 observation stations (shown in Figure 1) over the Tibetan Plateau during $1247 \quad 1961-2014$. 


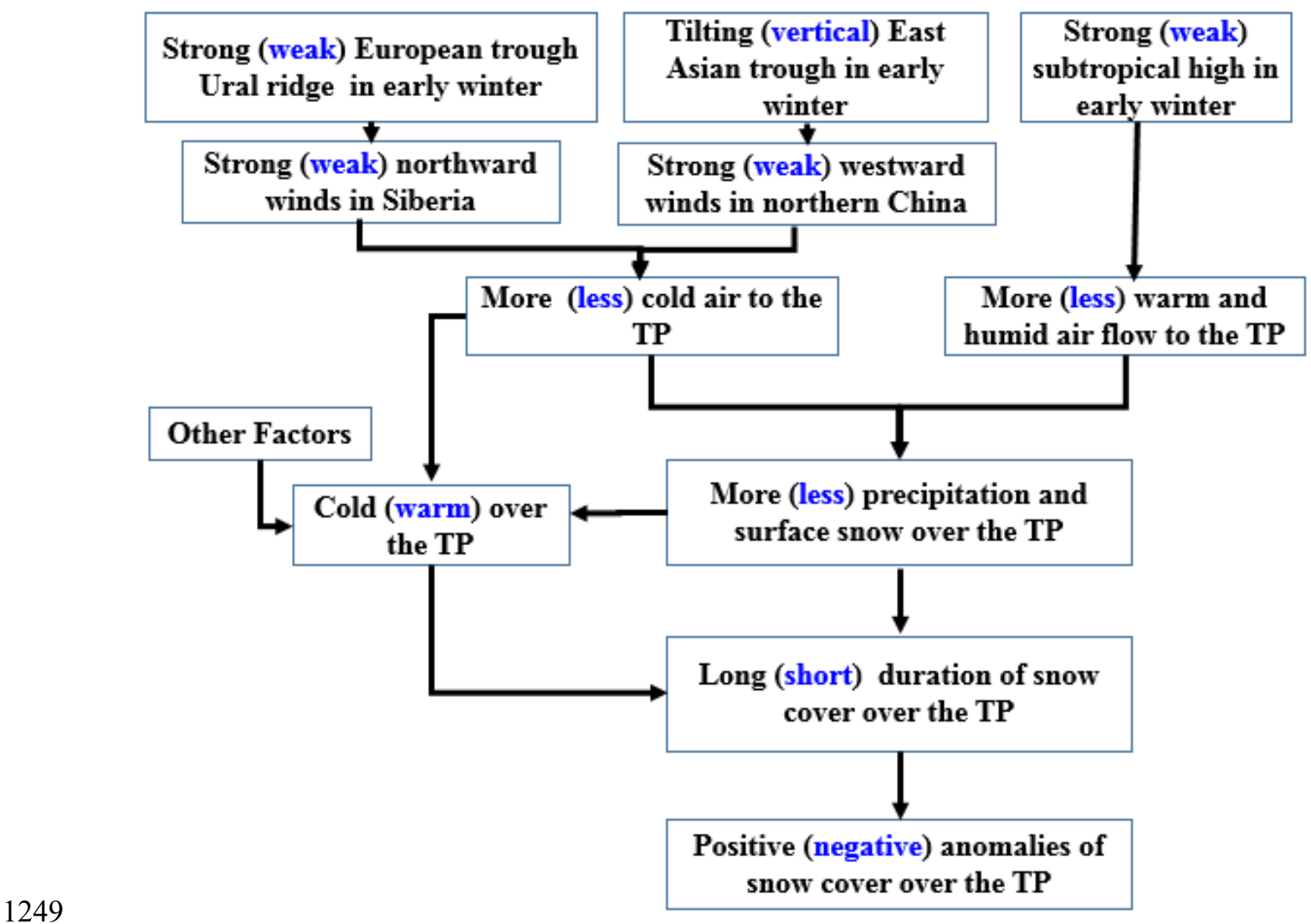

1250 Figure 3. Schematic diagram of factors contributing to variation of snow cover over the Tibetan Plateau. This is a summary graphic derived from previous studies [Duan et al., 2018; D Li and Wang, 2011; Luo, 1995; Tao and Ding, 1981; S Wang, 2017; $R$ 


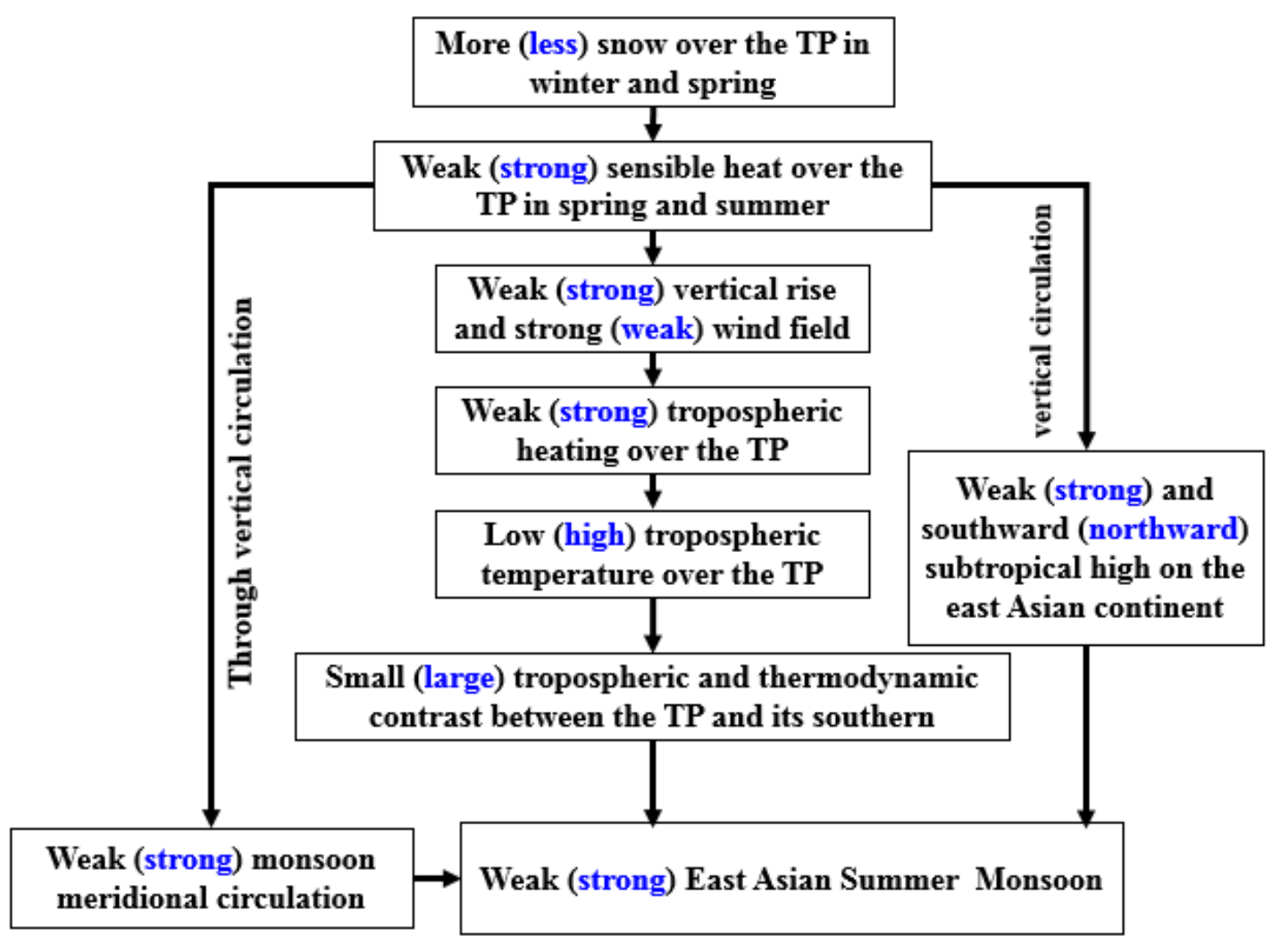

Figure 4. Possible mechanisms relating snow cover over the Tibetan Plateau with the

1264 East Asian Summer Monsoon. This schematic is based on Figure 13 in Zhang and Tao 1265 [2001]. 


\begin{tabular}{|c|c|}
\hline Anomaly of snow cove & vinter/spring over the TP \\
\hline More snow cover & Less snow cover \\
\hline $\begin{array}{l}\text { Weak sensible heat and surface heat source, } \\
\text { weak heat source in summer }\end{array}$ & $\begin{array}{l}\text { Strong sensible heat and surface heat source, } \\
\text { strong heat source in summer }\end{array}$ \\
\hline$\downarrow$ & $\downarrow$ \\
\hline $\begin{array}{l}\text { Dominant zonal airflow in mid-latitude, and } \\
\text { weaker and eastward East Asian trough }\end{array}$ & $\begin{array}{l}\text { Dominant meridional airflow in mid-latitude, } \\
\text { and strong and westward East Asian trough }\end{array}$ \\
\hline $\begin{array}{l}\text { Weak winter cumulus convection in the } \\
\text { southern South China Sea, and weak upper } \\
\text { divergence and Walker circulation }\end{array}$ & $\begin{array}{l}\text { Strong winter cumulus convection in the } \\
\text { southern South China Sea, and strong upper } \\
\text { divergence and Walker circulation }\end{array}$ \\
\hline$\downarrow$ & $\downarrow$ \\
\hline $\begin{array}{l}\text { Weak signal of Equatorial Pacific in winter } \\
\text { and spring, and eastward warm water and } \\
\text { more ENSO events; high/low SSTA in the } \\
\text { south/north northern Indian Ocean and weak } \\
\text { summer monsoon in subsequent year }\end{array}$ & $\begin{array}{l}\text { Strong signal of Equatorial Pacific in spring, } \\
\text { and upwelling cold water in central and eastern } \\
\text { Pacific ocean; low/high SSTA in the south/north } \\
\text { northern Indian Ocean and strong summer } \\
\text { monsoon in subsequent year }\end{array}$ \\
\hline $\begin{array}{c}\text { More floods in the middle and lower reaches } \\
\text { of the Yangtze River, less precipitation in } \\
\text { North China }\end{array}$ & $\begin{array}{l}\text { More droughts in the middle and lower reaches } \\
\text { of the Yangtze River, more precipitation in } \\
\text { North China }\end{array}$ \\
\hline
\end{tabular}

1272 Figure 5. Schematic diagram for physical processes linking snow cover over the

1273 Tibetan Plateau with variation in East Asian Summer Monsoon precipitation. This

1274 schematic is based on Figure 7 in Chen et al. [2000]. 


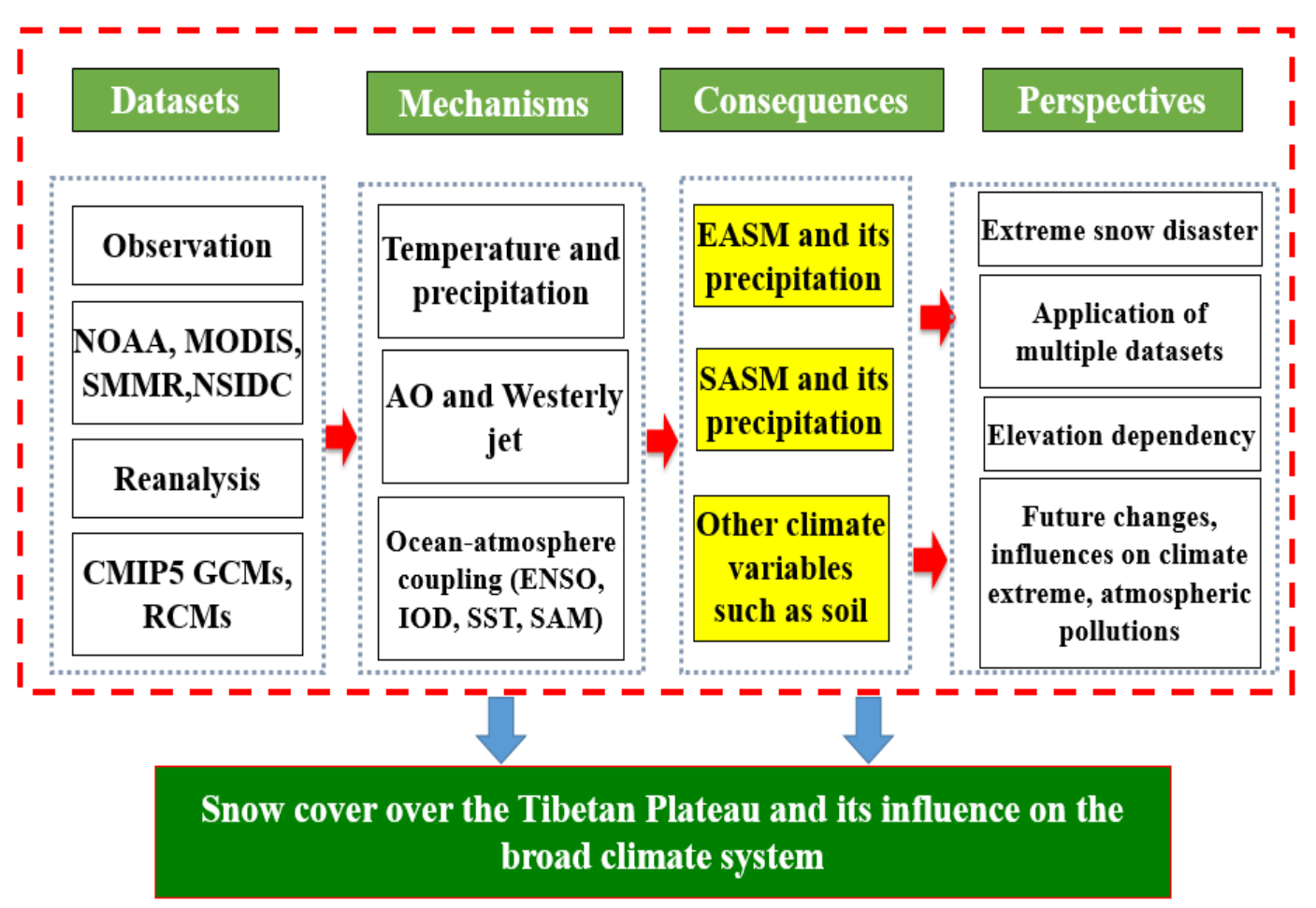

1284 Figure 6. Schematic diagram linking datasets, mechanisms, consequences and 1285 perspectives concerning snow cover over the Tibetan Plateau. 